\title{
Wintertime aerosol chemical composition and source apportionment of the organic fraction in the metropolitan area of Paris
}

\author{
M. Crippa ${ }^{1}$, P. F. DeCarlo ${ }^{1, *}$, J. G. Slowik ${ }^{1}$, C. Mohr ${ }^{1,{ }^{* *}}$, M. F. Heringa ${ }^{1,{ }^{* * *}}$, R. Chirico ${ }^{1,{ }^{* * * * *}}$, L. Poulain ${ }^{2}$, F. Freutel ${ }^{3}$, \\ J. Sciare ${ }^{4}$, J. Cozic ${ }^{5}$, C. F. Di Marco ${ }^{6}$, M. Elsasser ${ }^{7,8}$, J. B. Nicolas ${ }^{4}$, N. Marchand ${ }^{9}$, E. Abidi ${ }^{9}$, A. Wiedensohler ${ }^{2}$, \\ F. Drewnick ${ }^{3}$, J. Schneider ${ }^{3}$, S. Borrmann ${ }^{3,10}$, E. Nemitz ${ }^{6}$, R. Zimmermann ${ }^{7,8}$, J.-L. Jaffrezo ${ }^{5}$, A. S. H. Prévôt ${ }^{1}$, and \\ U. Baltensperger ${ }^{1}$ \\ ${ }^{1}$ Laboratory of Atmospheric Chemistry, Paul Scherrer Institute, PSI Villigen, 5232, Switzerland \\ ${ }^{2}$ Leibniz Institut for Tropospheric Research, Permoserstr 15, 04318, Leipzig, Germany \\ ${ }^{3}$ Particle Chemistry Department, Max-Planck-Institute for Chemistry, 55128 Mainz, Germany \\ ${ }^{4}$ Laboratoire des Sciences du Climat et de l'Environnement (LSCE/IPSL), Laboratoire CEA-CNRS-UVSQ, \\ 91191 Gif-sur-Yvette, France \\ ${ }^{5}$ UJF - Grenoble 1/CNRS, Laboratoire de Glaciologie et Géophysique de l'Environnement (LGGE) UMR5183, \\ Grenoble, 38041, France \\ ${ }^{6}$ Centre for Ecology and Hydrology, Bush Estate, Penicuik, Midlothian, EH26 0QB, UK \\ ${ }^{7}$ Joint Mass Spectrometry Centre, Cooperation Group Comprehensive Molecular Analytics, Helmholtz Zentrum München, \\ Ingolstädter Landstr. 1, 85764 Neuherberg, Germany \\ ${ }^{8}$ Joint Mass Spectrometry Centre, Universität Rostock, Institut für Chemie, Lehrstuhl für Analytische Chemie, \\ Dr.-Lorenz-Weg 1, 18059 Rostock, Germany \\ ${ }^{9}$ Aix-Marseille Université, CNRS, LCE FRE 3416, 13331, Marseille, France \\ ${ }^{10}$ Institute for Atmospheric Physics, Johannes Gutenberg University, Mainz, Germany \\ *now at: Department of Civil, Architectural, and Environmental Engineering, Drexel University, Philadelphia, \\ PA 19104, USA \\ *** now at: Department of Atmospheric Sciences, University of Washington, Seattle, WA 98195, USA \\ **** now at: WIL Research, 5203 DL 's-Hertogenbosch, The Netherlands \\ ***** now at: Italian National Agency for New Technologies, Energy and Sustainable Economic Development (ENEA), \\ UTAPRAD-DIM, Via E. Fermi 45, 00044 Frascati, Italy
}

Correspondence to: A. S. H. Prévôt (andre.prevot@psi.ch)

Received: 23 July 2012 - Published in Atmos. Chem. Phys. Discuss.: 31 August 2012

Revised: 13 December 2012 - Accepted: 4 January 2013 - Published: 23 January 2013

\begin{abstract}
The effect of a post-industrial megacity on local and regional air quality was assessed via a month-long field measurement campaign in the Paris metropolitan area during winter 2010. Here we present source apportionment results from three aerosol mass spectrometers and two aethalometers deployed at three measurement stations within the Paris region. Submicron aerosol composition is dominated by the organic fraction (30-36\%) and nitrate (28-29\%), with lower contributions from sulfate (14-16\%), ammonium (12-14\%) and black carbon (7-13\%).
\end{abstract}

Organic source apportionment was performed using positive matrix factorization, resulting in a set of organic factors corresponding both to primary emission sources and secondary production. The dominant primary sources are traffic (11-15\% of organic mass), biomass burning (13-15\%) and cooking (up to $35 \%$ during meal hours). Secondary organic aerosol contributes more than $50 \%$ to the total organic mass and includes a highly oxidized factor from indeterminate and/or diverse sources and a less oxidized factor related to wood burning emissions. Black carbon was apportioned to traffic and wood burning sources using a model based on 
wavelength-dependent light absorption of these two combustion sources. The time series of organic and black carbon factors from related sources were strongly correlated. The similarities in aerosol composition, total mass and temporal variation between the three sites suggest that particulate pollution in Paris is dominated by regional factors, and that the emissions from Paris itself have a relatively low impact on its surroundings.

\section{Introduction}

The last two centuries have seen the global rise of densely populated urban areas. Megacities, defined as urban areas with a population of over 10 million people (Molina and Molina, 2004a), potentially serve as major sources of gas and particle emissions. Evaluation of megacity air pollution and its effects on the surrounding areas is required for the formulation of effective air quality policy (Lawrence et al., 2007; Gurjar et al., 2008). For this reason, intensive field measurement campaigns have been proposed to investigate megacity effects on regional air quality. Here results are discussed from the intensive measurement phase of the MEGAPOLI project (Megacities: Emissions, urban, regional and Global Atmospheric POLlution and climate effects, and Integrated tools for assessment and mitigation, http://megapoli.dmi.dk/index. html), focused on Paris (France). This experimental phase of MEGAPOLI is modeled on the example of the MILAGRO campaign performed in the Mexico City metropolitan area during 2006 (Molina et al., 2010; Molina and Molina, 2004b). Integration of the Paris MEGAPOLI dataset with existing datasets for other megacities will lead to a more comprehensive assessment of the effect of megacity air pollution on atmospheric composition, air quality, and climate, covering local to global scales. Paris is one of the largest European megacities, with a population of approximately 12 million (including its surroundings). As a modern megacity, Paris may have a significantly different pattern of anthropogenic emissions than, for example, Mexico City, but more similarities to European agglomerations, such as London (Allan et al., 2010). Compared to worldwide megacities situated in developing countries, Paris is characterized by having modernized, less polluting factories and major anthropogenic activities spread across the metropolitan area. Therefore it can be considered as a post-industrial megacity. A detailed assessment of the factors controlling Paris air quality is therefore crucial for evaluating global megacity characteristics.

Within the broader context of Paris air quality, this study focuses specifically on the quantification of submicron aerosol sources affecting Paris. Aerosols consist of small solid or liquid particles suspended in the atmosphere. Their important effects on the environment, ecosystems, human health (Dockery and Pope, 1994; Pope and Dockery, 2006), and climate (IPCC, 2007) are well-recognized. Aerosol cli- mate effects occur by perturbation of the Earth's radiative budget, both directly through scattering and absorption of solar and terrestrial radiation, and indirectly by acting as cloud condensation nuclei (Albrecht, 1989; Twomey et al., 1984). Quantification of these aerosol effects is highly uncertain, in large part due to the organic fraction. Organic aerosol (OA) is ubiquitous in the atmosphere, constituting from 20 to $90 \%$ of the total submicron aerosol mass (Jimenez et al., 2009), and is difficult to accurately model due to the complexity of its sources, composition and atmospheric aging mechanisms. $\mathrm{OA}$ is typically classified as either primary organic aerosol (POA), or secondary organic aerosol (SOA). POA is directly emitted into the atmosphere by anthropogenic sources such as traffic, industry and domestic combustion, and by natural processes such as wildfires. Secondary organic aerosol species are formed in the air through physical and chemical processes such as oxidation, followed by nucleation or condensation. While submicron secondary inorganic aerosols are mainly composed of ammonium nitrate and sulfate (Seinfeld and Pandis, 2006), SOA may be composed of thousands of compounds, many of which are unknown (Goldstein et al., 2008), and further uncertainties exist in SOA formation pathways (Hallquist et al., 2009). Investigation of both direct emission sources and secondary formation mechanisms is crucial to better understand the behavior of aerosol particles and constrain their uncertainty in climate models (IPCC, 2007; Volkamer et al., 2006).

Highly time-resolved measurement techniques, such as aerosol mass spectrometry, have been developed to characterize complex and rapidly changing OA sources. Receptor models have been utilized to represent the observed mass concentration, chemical composition or other additive aerosol properties as a linear combination of factor profiles and time series. Examples of such models include $\mathrm{m} / \mathrm{z}$ tracer apportionment, positive matrix factorization (PMF), and multi-linear engine (ME-2) (Lanz et al., 2007, 2008, 2010; Ulbrich et al., 2009; Zhang et al., 2011).

Recent studies have investigated aerosol characteristics and behavior in the Paris region, including aethalometer measurements of wood burning emissions (Favez et al., 2009), source apportionment of volatile organic compounds (VOCs) during spring (Gaimoz et al., 2011) and the quantification of wintertime carbonaceous material and inorganic ions (Sciare et al., 2011). Our work complements these efforts by identifying the major aerosol sources in the Paris region, focusing on particle chemical speciation of the submicron fraction and OA source apportionment. This requires chemically-specific measurements with high time resolution, coupled to sophisticated data analysis techniques. In our work, non-refractory particle composition is measured with aerosol mass spectrometers (Drewnick et al., 2005; DeCarlo et al., 2006; Canagaratna et al., 2007) and analysed with positive matrix factorization (Paatero and Tapper, 1994; Paatero, 1997). Optical measurements of black carbon mass are apportioned to traffic and wood burning sources using a model based on 
the wavelength dependence of the aerosol light absorption coefficient (Sandradewi et al., 2008). Black carbon (BC) is the principal source of particulate light absorption, therefore its source apportionment is important for quantifying aerosol effects on climate through direct interaction with solar radiation (Bond and Bergstrom, 2006). Comparison of these two independent apportionment efforts helps to validate the results of each other and provides insight into the variations caused by regional versus local sources.

\section{Methodologies}

\subsection{Measurement campaign}

As noted above, the greater Paris area (population 12 million) is one of the largest metropolitan areas in Europe. This densely populated area consists of a circular region with a diameter of $20 \mathrm{~km}$ and is surrounded by flat, rural terrain. The morphology of the region and the relative isolation of Paris from other urban areas make it a suitable location for the investigation of both megacity effects on regional air quality and the physical and chemical evolution of urban pollutants within the Paris plume.

As part of the MEGAPOLI project, an intensive, monthlong field measurement campaign was performed in Paris during winter 2010 (12 January-16 February). Measurements were performed at three stationary ground sites, located in both the urban core and urban background areas around Paris. A map of the measurement sites is provided in Sect. 1 of the Supplement. Mobile measurements were also performed throughout Paris; however this work focuses only on the stationary measurements. The urban core site was located at "Le laboratoire d'hygiène de la Ville de Paris" ("LHVP", $48.83^{\circ}$ Latitude, $2.36^{\circ}$ Longitude, $55 \mathrm{~m}$ a.s.1.) situated in the 13th Arrondissement of Paris in the southeastern part of the city center. Several field experiments performed at this station indicate that the LHVP site is representative of the particulate pollution of the center of Paris (Favez et al., 2007; Sciare et al., 2010). The two urban background stations ("SIRTA" and "GOLF" sites) were located to the northeast and southwest of Paris, $20 \mathrm{~km}$ from the city center. The "Site Instrumental de Recherche par Télédétection Atmosphérique" ("SIRTA", Latitude $48.71^{\circ} \mathrm{N}$, Longitude $2.21^{\circ} \mathrm{E}$, 60 ma.s.1.) was located on the campus of the École Polytechnique in Palaiseau ( $20 \mathrm{~km}$ southwest of Paris center) in a semi-urban environment surrounded by cultivated areas, forests, small towns and few industrial activities (Haeffelin et al., 2005). Major roads and highways connecting the periphery to the city intersect a few kilometres from the SIRTA site. The station is surrounded by fields to the north/northeast, and by residential areas and villages to the south and east.

The GOLF site was located in Livry-Gargan, $20 \mathrm{~km}$ northeast of Paris center $\left(48.93^{\circ} \mathrm{N}\right.$ Latitude, $2.55^{\circ}$ E Longitude, 60 $\mathrm{m}$ a.s.l.) in a small parking lot at the southeast end of the Golf de la Poudrerie. A park and a visitor parking lot lie northeast of the site, with some road construction occurring during the campaign about 100-120 $\mathrm{m}$ away. The site is bordered on the south by gardens, and it is about $30 \mathrm{~m}$ to the nearest road.

Additionally, measurements performed in a rural station located at approximately $58 \mathrm{~km}$ northeast of Paris $\left(49.087^{\circ} \mathrm{N}\right.$ Latitude, $3.077^{\circ}$ E Longitude) will be discussed in Sect. 3.4.

\subsection{Instrumentation}

\subsubsection{Aerosol mass spectrometers and sampling lines}

High-resolution time-of-flight aerosol mass spectrometers (HR-ToF-AMS) (DeCarlo et al., 2006) were deployed at both the SIRTA and LHVP sites, while a compact ToF-AMS (CToF-AMS) (Drewnick et al., 2005) was deployed at GOLF. The AMS measures quantitative, size-resolved mass spectra of the non-refractory (NR) species in $\mathrm{PM}_{1}$ (particulate matter with an aerodynamic diameter $d<1 \mu \mathrm{m}$ ) aerosol, where NR species are operationally defined as those that flash vaporize at $600^{\circ} \mathrm{C}$ and $\sim 10^{-5}$ Torr. These NR species include particle components except black carbon, sea salt, mineral dust, and metals. A detailed description of these instruments can be found in Drewnick et al. (2005) for the C-ToF and in DeCarlo et al. (2006) for the HR-ToF-AMS. Briefly, aerosols are sampled through an aerodynamic lens, where they are focused into a narrow beam and accelerated to a velocity inversely related to their aerodynamic size. The particles are transmitted into a high vacuum detection chamber $\left(\sim 10^{-5}\right.$ Torr $)$, where the NR components impact a resistively-heated surface $\left(600^{\circ} \mathrm{C}\right)$ and flash vaporize. The resulting gas molecules are ionized by electron impact (EI, $\sim 70 \mathrm{eV}$ ) and analyzed by time-of-flight mass spectrometry. The particle beam may be either (1) alternately blocked and unblocked to yield a mass spectrum of the particle ensemble termed Mass Spectrum (MS) mode, or (2) modulated by a spinning chopper wheel $(\sim 150 \mathrm{~Hz})$ to yield size-resolved mass spectra called Particle Time-of-Flight (PToF) mode (Drewnick et al., 2005). AMS spectra were recorded with a time resolution of 1,5 , and $10 \mathrm{~min}$ at the GOLF, LHVP, and SIRTA sites, respectively, with the details of the sampling protocols described below.

The C-ToF-AMS was deployed at GOLF from 16 January 2010 to 16 February 2010 and was located within a measurement container along with several other instruments for aerosol particle characterization (see Sect. 2.2.3). The sampling inlet (flow rate of $\sim 100 \mathrm{~L} \mathrm{~min}^{-1}$ ) was located at $\sim 8 \mathrm{~m}$ above the ground and several impactors and instruments with high flows were connected. The particles were transmitted from the main inlet to the AMS through $4 \mathrm{~m}$ of $1 / 4^{\prime \prime}$ outer diameter (o.d.) stainless steel tubing at a flow rate of about $1.1 \mathrm{~L} \mathrm{~min}^{-1}$. The tubing in the container was insulated and the aerosol was not dried. No impactor was located in front of the main inlet, but a separate cyclone $\left(\mathrm{PM}_{1}\right)$ was deployed for the MAAP (Multi-Angle Absorption Photometer). The 
C-ToF alternated between $20 \mathrm{~s}$ in MS mode, $20 \mathrm{~s}$ in PToF mode and $20 \mathrm{~s}$ in light scattering/single particle mode (Cross et al., 2009).

A HR-ToF-AMS was deployed at LHVP from 12 January 2010 to 16 February 2010 together with a suite of instrumentation for the characterization of physical-chemical particle properties. All instruments were connected to the same sampling system. This consisted of a $\mathrm{PM}_{10}$ inlet $\sim 6 \mathrm{~m}$ above ground directly followed by an automatic aerosol diffusion dryer system that maintained the relative humidity in the line below $30 \%$. The AMS alternated between lower and higher mass resolution modes ( $\mathrm{V}$ and $\mathrm{W}$, respectively) every $5 \mathrm{~min}$. In $\mathrm{V}$ mode it sampled for 20 and $40 \mathrm{~s}$ in the MS and PToF modes respectively, while only MS sampling was conducted in $\mathrm{W}$ mode.

The HR-ToF-AMS deployment at SIRTA ran from 13 January 2010 to 15 February 2010. The AMS was connected downstream of a particle thermodenuder (TD) system similar to Lee et al. (2010), the results from which will be presented elsewhere. The SIRTA AMS was located in a trailer $(6.4 \mathrm{~m} \times 1.95 \mathrm{~m})$, with the $\mathrm{PM}_{10}$ main inlet fixed atop an external tripod $\sim 4 \mathrm{~m}$ above ground. The main sampling line was built with $3 / 8^{\prime \prime}$ o.d. stainless steel tubing and had a flow of $16.4 \mathrm{~L} \mathrm{~min}^{-1}$. Inside the trailer the total flow was divided into $11.4 \mathrm{~L} \mathrm{~min}^{-1}$ to provide the necessary flow for several instruments (Nephelometer, SP2, VHTDMA, CCNC, etc.) and $5 \mathrm{~L} \mathrm{~min}^{-1}$ for the AMS-TD system and the aethalometer. The AMS-TD sampling line consisted of $6 \mathrm{~mm}$ o.d. stainless steel tubing with a total flow of $1 \mathrm{~L} \mathrm{~min}^{-1}$. The aerosol was not dried, and the trailer temperature was maintained at $20^{\circ} \mathrm{C}$. The SIRTA AMS alternated MS and PToF modes with a period of $5 \mathrm{~s}$ in the $\mathrm{V}$ configuration and remained only in MS mode for the $\mathrm{W}$ configuration, with data saved every 150 $\mathrm{s}$ for both configurations. Ambient and thermodenuder measurements alternated every $5 \mathrm{~min}$ yielding $2.5 \mathrm{~min}$ of ambient $\mathrm{V}$ mode measurements every $10 \mathrm{~min}$. Two additional AMS were used in two mobile laboratories (see Sect. 2 of the Supplement), but detailed analysis on the performed mobile measurements will be presented in separate publications.

AMS spectra were analyzed using the toolkit provided by Aerodyne and the University of Colorado-Boulder (Squirrel v1.51, D. Sueper, University of Colorado-Boulder, Boulder, CO, USA) for the IGOR Pro software package (Wavemetrics, Inc., Portland, OR, USA). Ionization efficiency calibrations and collection efficiency corrections due to particle bounce $\left(E_{\mathrm{b}}\right)$ were applied to the data (Canagaratna et al., 2007) and the air interferences were accounted for in the fragmentation table (Aiken et al., 2008; Allan et al., 2004). The collection efficiency due to particle bounce $\left(E_{\mathrm{b}}\right)$ was estimated at 0.5 for the SIRTA and GOLF sites and 0.4 for the LHVP site by comparison with independent measurements at each location (see SI-1 and SI-2). Additional intercomparisons between the AMS and collocated instruments were performed to assess the uncertainty associated with both measurements (see SI-3).
Relative ionization efficiencies (RIE) for ammonium $\left(\mathrm{NH}_{4}^{+}\right)$and sulfate $\left(\mathrm{SO}_{4}^{2-}\right)$ were determined by laboratory experiments with $\left(\mathrm{NH}_{4}\right)_{2} \mathrm{SO}_{4}$ and calibrations with $\mathrm{NH}_{4} \mathrm{NO}_{3}$ during the campaign. $\mathrm{RIE}_{\mathrm{NH}_{4}}$ was equal to 4 for the SIRTA and LHVP sites while equal to 4.05 for GOLF. The default RIE values for $\mathrm{SO}_{4}$ were assumed for SIRTA and LHVP since no ammonium sulfate calibrations were performed while for GOLF was 0.76 from $\left(\mathrm{NH}_{4}\right)_{2} \mathrm{SO}_{4}$ calibrations.

A scaling factor of 1.3 was applied to the organic concentrations measured at the stationary GOLF site after comparison with the mobile laboratory deployed at the same location (Freutel et al., 2013). This factor is attributed to the lower ion transmission efficiency for high $\mathrm{m} / \mathrm{z}$ observed for the CToF-AMS during the campaign, which also causes the lower $\mathrm{RIE}_{\mathrm{SO}_{4}}$ of this instrument (see SI-3b).

\subsubsection{The 7-wavelength aethalometer}

7-wavelength aethalometers (MAGEE Scientific, model AE31-ER) were operated at the SIRTA and LHVP sites. These instruments collect aerosol particles on a quartz fiber filter and measure the resulting light attenuation $\left(\mathrm{ATN}=\mathrm{I}_{0} / \mathrm{I}\right)$ at $370,470,520,590,660,880$, and $950 \mathrm{~nm}$. This yields the aerosol absorption coefficient $\left(b_{\mathrm{abs}}\right)$, defined by the BeerLambert's law as:

$I=I_{0} \cdot e^{-b_{\mathrm{abs}} \cdot x}$

where $I_{0}$ is the intensity of the incoming light and $I$ is its intensity after passing through the filter medium with thickness $x$. In addition to aerosol light absorption, attenuation in the aethalometer is affected by multiple scattering from the filter membrane, and by a shadowing effect due to impacted particles at high mass accumulation. These effects were corrected using a previously published algorithm (Weingartner et al., 2003). The black carbon (BC) mass concentration was estimated from the $b_{\text {abs }}$ measurements using a mass absorption efficiency (MAE equal to $5.78 \mathrm{~m}^{2} \mathrm{gC}^{-1}$ at $880 \mathrm{~nm}$ ) obtained by comparison of the aethalometer with elemental carbon (EC) data from a semi-continuous Sunset OCEC field analyzer (Sunset Laboratory, Forest Grove, OR, USA) which was operated at LHVP in $\mathrm{PM}_{2.5}$ during the MEGAPOLI campaign (Sciare et al., 2013). This comparison was performed using the $880-\mathrm{nm}$ channel for the aethalometer, which is less affected by optically-absorbing brown carbon (Kirchstetter et al., 2004). Both aethalometers recorded data with 5-min time resolution and operated with a $50 \%$ size cut-off of $2.5 \mu \mathrm{m}$ aerodynamic diameter.

\subsubsection{Other instruments}

Data from several additional instruments deployed at the SIRTA and LHVP sites were used in estimating the AMS collection efficiency and validating the PMF results. These instruments included a particle-into-liquid sampler (Orsini et al., 2003) coupled with two ion chromatographs (PILS-IC) 
and filter collection for off-line analyses. A brief description of these measurements follows.

The PILS-IC measures the chemical composition of selected inorganic species in $\mathrm{PM}_{2.5}$. In this instrument, the aerosols are grown into droplets prior to collection by inertial impaction on a quartz surface. Two ion chromatographs are used for separation and quantification of the main inorganic species $\left(\mathrm{Na}^{+}, \mathrm{NH}_{4}^{+}, \mathrm{K}^{+}, \mathrm{Ca}^{2+}, \mathrm{Mg}^{2+}, \mathrm{Cl}^{-}, \mathrm{NO}_{3}^{-}, \mathrm{SO}_{4}^{2-}\right)$. Chromatograms were obtained every 4 and $10 \mathrm{~min}$ for the LHVP and SIRTA sites, respectively. Settings used here for the PILS-IC measurements are similar to those reported in Sciare et al. (2011).

Collection of $\mathrm{PM}_{2.5}$ particles on high volume DIGITEL filters for off-line chemical analyses took place at both the SIRTA and LHVP stations with $12 \mathrm{~h}$ time resolution. Levoglucosan was measured by liquid chromatography - electrospray ionisation - tandem mass spectrometry (LC-ESIMS/MS) (Piot et al., 2012). OC and EC were measured by an ECOC Sunset laboratory analyzer (Birch and Cary, 1996) using the EUSAAR 2 method (Cavalli et al., 2010). Stearic acid was analyzed by gas chromatography-mass spectrometry (GC/MS) following the analytical methodology described in El Haddad et al. (2011) and quantified using an authentic standard. A comparison between the organic carbon mass concentration estimated from the high resolution AMS analysis and the OC concentration obtained from the filters is presented in the Supplement (SI-4).

Meteorological data (e.g shown in Fig. 12) were derived from radiosonde measurements at SIRTA. Wind speed and direction measurements reported here were obtained at an altitude of $100 \mathrm{~m}$ above ground level (a.g.l.). SIRTA includes a permanent deployment of active and passive remote sensing techniques for monitoring cloud, aerosol, and meteorological parameters (Haeffelin et al., 2005). $\mathrm{NO}_{\mathrm{x}}$ concentrations were measured at GOLF by an AirPointer (recordum Messtechnik $\mathrm{GmbH}$ ) which uses a molybdenum converter and chemiluminescence detector, while at SIRTA and LHVP a chemiluminescence instrument (Environment S.A., Model AC31M) was used. The $\mathrm{BC}\left(\mathrm{PM}_{1}\right)$ mass concentration was provided by a MAAP (Thermo Scientific, model 5012) at the GOLF site.

Additionally, SMPS (scanning mobility particle sizer), FDMS-TEOM (filter dynamics measurement system-tapered element oscillating microbalance) and TDMPS (tandem differential mobility particle sizer) measurements were used to estimate $E_{\mathrm{b}}$ for the AMS (see Sect. 2 in the Supplement).

\subsection{Source apportionment techniques}

\subsubsection{Positive matrix factorization}

Positive matrix factorization (PMF) is a bilinear unmixing receptor-only model used to describe measurements (in this case the matrix of AMS organic mass spectra as a function of time) as a linear combination of several static factors, as shown in Eq. (2) (Paatero and Tapper, 1994):

$x_{i j}=\sum_{k=1}^{p}\left(g_{i k} \cdot f_{k j}\right)+e_{i j}$

Here $x_{i j}, f_{k j}, g_{i k}$, and $e_{i j}$ are matrix elements of the measurement, factor profile, factor time series, and residual matrices, respectively. The subscript $i$ corresponds to $m / z, j$ corresponds to time, and $k$ corresponds to a discrete factor. The number of factors in the PMF solution is determined by the user and denoted as $p$. Note that in Eq. (2) the factor profiles are static, but their concentrations are allowed to vary with time. Additionally, PMF requires that all $f_{i j}$ and $g_{i j}$ are $\geq 0$.

The PMF algorithm attempts to minimize the object function $Q$, defined as

$Q=\sum_{i} \sum_{j}\left(e_{i j} / s_{i j}\right)^{2}$

where $s_{i j}$ is the measurement error.

The AMS uncertainty matrix accounts for electronic noise, ion-to-ion variability at the detector, and ion counting statistics (Allan et al., 2003). For all $x_{i j}$, a minimum counting of 1 ion is applied (Ulbrich et al., 2009). Following the recommendation of Paatero and Hopke (2003), $m / z$ with low signal-to-noise $\left(\mathrm{SNR}<0.2\right.$, where $\left.\mathrm{SNR}=\sqrt{\sum x_{i j}^{2} / \sum s_{i j}^{2}}\right)$ are removed, whereas "weak" variables $(0.2<\mathrm{SNR}<2)$ are downweighted. Downweighting is performed by increasing the error of the weak variables by a factor of 2 , thus reducing the influence of these points in the PMF model, because they are presumed to be strongly affected by noise.

In the AMS data analysis procedure, certain organic peaks are not directly measured but rather calculated as a fraction of the organic signal at $m / z 44$ (Allan et al., 2004). The errors for these $m / z$ are adjusted to prevent overweighting of the $\mathrm{m} / z 44$ signal following the method of Ulbrich et al. (2009); of these $m / z$ 44-dependent peaks, $m / z, 19$ and 20 are simply removed due to their negligible masses (Ulbrich et al., 2009).

The PMF analyses were conducted using the CU AMS PMF Evaluation Tool (PET) version 2.02B (Ulbrich et al., 2009) which serves as a front end for the PMF2 model (Paatero, 2007).

In this work, PMF analysis was applied on organic fragments with $m / z \leq 300$ for all three sites. These $m / z$ account for more than $99 \%$ of the total organic mass, with 90\% of the mass occurring below $m / z$ 100. For HR-ToF-AMS data, only unit mass resolution MS from V-mode data were used for PMF because of their higher SNR.

The selection of the number of factors used to describe the observations is subjective, but it can be assessed using several criteria. These include (1) comparisons of the factor mass spectra with reference profiles obtained from other field campaigns (http://cires.colorado.edu/ jimenez-group/AMSsd/\#Ambient), (2) comparison of the factor time series with ancillary measurements performed 
during the Paris campaign, and (3) evaluation of the Q-value. $Q$ corresponds to the number of the degrees of freedom of the system $\left(Q_{\text {expected }}=Q_{\exp }=m n-p(m+n)\right.$, where $m$ and $n$ are the dimensions of the matrix and $p(m+n)$ the free parameters fitted to the data. Assuming that all the errors are Gaussian in distribution, $Q / Q_{\exp }>>1$ if the errors are underestimated or the identified sources can not describe completely the variability of the measurements, while $Q / Q_{\exp }<1$ if the errors of the input data have been overestimated (Paatero et al., 2002). The dependence of this ratio on $p$ is explored in the Sect. 6 of the Supplement. $Q$ decreases as factors are added because the free parameters of the model increase. Analysis of the variation of $Q / Q_{\exp }$ versus the number of factors allows the identification of the sources which are significant in the explanation of the data variability.

Solutions produced by the PMF model are not mathematically unique since equally correct solutions may be found through linear transformations (rotations) of the factor time series $(\mathbf{G})$ and mass spectra $(\mathbf{F})$ :

$\mathbf{G}_{0}=\mathbf{G} \cdot \mathbf{T}$

$\mathbf{F}_{0}=\mathbf{T}^{-1} \cdot \mathbf{F}$

$\mathbf{G}_{0} \mathbf{F}_{0}=\mathbf{G} \cdot \mathbf{T} \cdot \mathbf{T}^{-1} \cdot \mathbf{F}$

where $\mathbf{G}_{0}$ and $\mathbf{F}_{0}$ are the rotated matrix, $\mathbf{T}$ is the rotation matrix and $\mathbf{T}^{-1}$ its inverse.

Positive elements of the rotation matrix $\mathbf{T}$ create a rotation by adding the mass spectra and subtracting the corresponding time series, whereas the reverse occurs for negative elements of the rotation matrix (Paatero and Hopke, 2009). A subset of the possible rotations can be explored in PMF2 using the " $f_{\text {peak }}$ " parameter. The rotational ambiguity was analyzed in this work by varying the $f_{\text {peak }}$ parameter between -10 and 10. Some of the obtained solutions at given fpeaks were either non-convergent or not physically meaningful; a detailed description of the $f_{\text {peak }}$ analysis is presented in the Supplement. The solutions presented here use $f_{\text {peak }}=0$ for the SIRTA and GOLF sites and $f_{\text {peak }}=-0.1$ for LHVP. The selection of the $f_{\text {peak }}=-0.1$ solution for the LHVP site was motivated by the clearer separation obtained for several sources as discussed in Sect. SI-6.3.

The possibility of local minima for $Q$ (Paatero, 1997) was investigated by initializing the PMF2 algorithm with 50 different pseudo-random starting points ("seeds") (Paatero, 2007). These results are presented in SI 6.4.

\subsubsection{BC source apportionment}

Black carbon (BC) is defined as the visible light-absorbing component of carbonaceous aerosol. Here BC source apportionment is performed with a linear regression model utilizing the source-specific wavelength dependence of BC light absorption (Sandradewi et al., 2008). Aerosol absorption coefficients follow the relationship $b_{\mathrm{abs}}=\lambda^{-\alpha}$, where $\lambda$ is the wavelength and $\alpha$ the absorption Ångström exponent. Literature values of the BC absorption Ångström exponent vary between 1.9 and 2.2 for wood burning (Sandradewi et al., 2008) and $1 \pm 0.1$ for traffic (Bond and Bergstrom, 2006; Bond et al., 2004). In the present study absorption Ångström exponent values for traffic and wood burning were chosen as $\alpha_{\mathrm{tr}}=1$ and $\alpha_{\mathrm{bb}}=2$, respectively, coherently with Sciare et al. (2011). The choice of such $\alpha$ values is in agreement with previous sensitivity analyses performed in the Paris region in order to evaluate the influence of different absorption exponent values on the aethalometer model (Sciare et al., 2011).

Therefore using the aethalometer-measured absorption coefficient and a source-dependent $\alpha$ value, $b_{\text {abs }}$ can be apportioned to traffic $\left(b_{\mathrm{abs}, \mathrm{tr}}\right)$ and biomass burning $\left(b_{\mathrm{abs}, \mathrm{bb}}\right)$ sources (Sandradewi et al., 2008):

$\frac{b_{\mathrm{abs}}(470 \mathrm{~nm})_{\mathrm{tr}}}{b_{\mathrm{abs}}(880 \mathrm{~nm})_{\mathrm{tr}}}=\left(\frac{470}{880}\right)^{-\alpha_{\mathrm{tr}}}$

$\frac{b_{\mathrm{abs}}(470 \mathrm{~nm})_{\mathrm{bb}}}{b_{\mathrm{abs}}(880 \mathrm{~nm})_{\mathrm{bb}}}=\left(\frac{470}{880}\right)^{-\alpha_{\mathrm{bb}}}$

$b_{\mathrm{abs}}(\lambda)=b_{\mathrm{abs}}(\lambda)_{\mathrm{tr}}+b_{\mathrm{abs}}(\lambda)_{\mathrm{bb}}$

Apportionment of the black carbon mass concentration is calculated as follows:

$\mathrm{BC}_{\mathrm{tr}}=B C_{\mathrm{tot}} \cdot \frac{b_{\mathrm{abs}, \mathrm{tr}, 880 \mathrm{~nm}}}{b_{\mathrm{abs}, \mathrm{tot}, 880 \mathrm{~nm}}}$

$\mathrm{BC}_{\mathrm{bb}}=B C_{\mathrm{tot}} \cdot \frac{b_{\mathrm{abs}, \mathrm{bb}, 880 \mathrm{~nm}}}{b_{\mathrm{abs}, \mathrm{tot}, 880 \mathrm{~nm}}}$

\section{Results and discussion}

\subsection{Bulk $\mathrm{PM}_{1}$ chemical composition}

During the Paris winter campaign, the total submicron mass concentration of the non-refractory species measured by the AMS varied from a few $\mu \mathrm{g} \mathrm{m}^{-3}$ to $\sim 80 \mu \mathrm{g} \mathrm{m}^{-3}$. A comparison of the chemically-resolved mass concentration measured by the AMS at the 3 sites is presented in Fig. 1. Averaged over the entire campaign, $\mathrm{PM}_{1}$ particles consist of 30 $36 \%\left(5-6 \mu \mathrm{g} \mathrm{m}^{-3}\right)$ organics, 28-29\% (4-5 $\left.\mu \mathrm{g} \mathrm{m}^{-3}\right)$ nitrate, $12-14 \%\left(2 \mu \mathrm{g} \mathrm{m}^{-3}\right)$ ammonium, $14-16 \%\left(2-3 \mu \mathrm{g} \mathrm{m}^{-3}\right)$ sulfate, $0.8-1.2 \%\left(0.1-0.2 \mu \mathrm{g} \mathrm{m}^{-3}\right)$ chloride and $7-13 \%(1-$ $2 \mu \mathrm{g} \mathrm{m}^{-3}$ ) black carbon; the variability represents the mean values obtained at each site. The higher black carbon contribution measured at the GOLF site $(13 \%)$ probably results from its exposure to local traffic emissions and/or to the use 


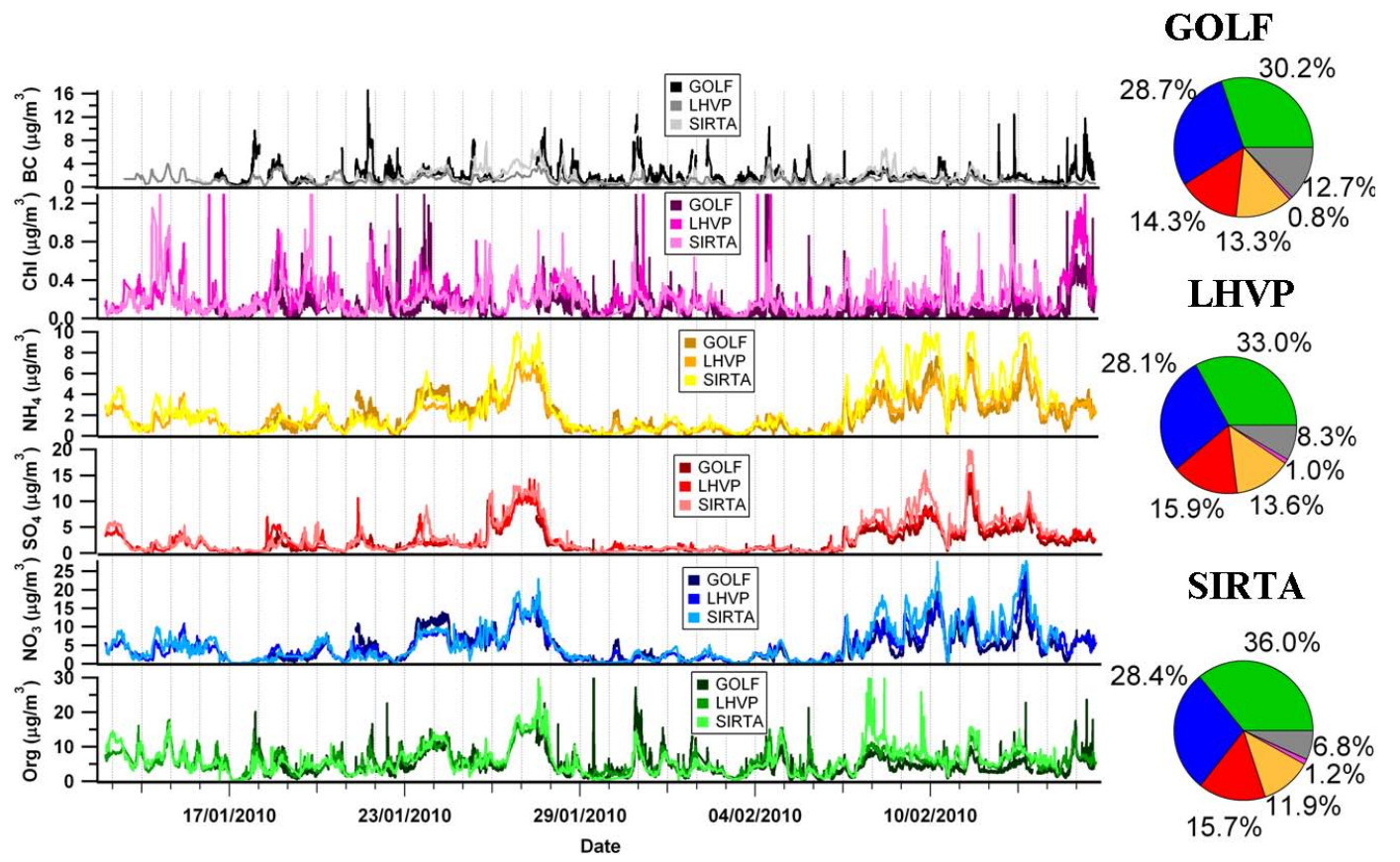

Fig. 1. Comparison of $\mathrm{PM}_{1}$ chemical composition from AMS (organics (Org), sulfates $\left(\mathrm{SO}_{4}^{2-}\right)$, nitrates $\left(\mathrm{NO}_{3}^{-}\right)$, ammonium $\left(\mathrm{NH}_{4}^{+}\right)$, chlorine (Chl)) and black carbon (BC) measurements in the Paris region.

of the MAAP instrument instead of the aethalometer to calculate $\mathrm{BC}$. The average composition and time series are surprisingly similar among the sites for both the organic and inorganic fractions. The relatively uniform chemical composition throughout the Paris area suggests that particle composition is dominated by regional factors rather than local emissions.

The observed homogeneity in terms of chemical composition, mass concentration and sources among the three sites could theoretically indicate a dominant impact of Paris on its surroundings, however the reduced impact of Paris itself on the surrounding air quality indicated the opposite conclusion. The urban core of Paris covers $\sim 20 \mathrm{~km}$ in diameter, while the greater Parisian metropolitan area is $\sim 40 \mathrm{~km}$ in diameter; the SIRTA and GOLF sites are located near the edges of this metropolitan area. Beekmann et al. (2013) showed that the yearly averaged impact of Paris emissions is equal to only $30 \%$ of $\mathrm{PM}_{2.5}$, while the remaining $70 \%$ is advected to Paris and impacted by long-range transport of continental pollution. Moreover $\mathrm{PM}_{1}$ levels measured at the GOLF site were much higher for air masses coming from central Europe than for air masses with SW winds, which contain the urban emissions from Paris during the summer and winter MEGAPOLI campaigns (Beekmann et al., 2013; Freutel et al., 2013). Crippa et al. (2013b) showed also the ability of Atlantic Ocean air masses to significantly influence air quality in the Paris urban core (200 km from the ocean), suggesting that particulate emissions from Paris are unlikely to be the major regional influence. Our results agree with the conclusions of Sciare et al. (2010) who reported long-range transport to be the major source of $\mathrm{PM}_{2.5}$ secondary aerosol in Paris during springtime.

Small mass concentration enhancements at the downwind vs. upwind urban background site with respect to the Paris agglomeration can be identified (e.g. on 23-24 and 30-31 January for the Golf site, on 26-27 January and from 8 February to the end of the campaign for the SIRTA site), and could also be caused by inhomogeneities in the regionally transported aerosol rather than the influence of the Paris plume. Local vs. regional effects on the aerosol composition are further discussed in Fig. 12 and Sect. 3.4.

The degree of aerosol neutralization is given by the ratio of the measured ammonium concentration $\left(\mathrm{NH}_{4}^{+}\right.$meas $)$to the amount of $\mathrm{NH}_{4}^{+}$needed for the neutralization of the anions measured by the AMS $\left(\mathrm{NH}_{4}^{+}\right.$neutr) (Eq. 10). Mean values for this ratio were $0.83 \pm 0.06,0.87 \pm 0.13$ and $1.04 \pm 0.23$ for LHVP, SIRTA and GOLF, respectively, therefore the aerosol was neutral within the uncertainty measurements range evaluated with the error propagation law (Zhang et al., 2007).

$$
\frac{\mathrm{NH}_{4}^{+} \text {meas }}{\mathrm{NH}_{4}^{+} \text {neutr }}=\frac{\mathrm{NH}_{4}^{+}}{18} /\left(\frac{2 \cdot \mathrm{SO}_{4}^{2-}}{96}+\frac{\mathrm{NO}_{3}^{-}}{62}+\frac{\mathrm{Cl}^{-}}{35.5}\right)
$$

This complete neutralization of sulfate and nitrate by ammonium is consistent with similar results obtained in parallel by the PILS-IC measurements at SIRTA and LHVP.

Similar diurnal patterns are also observed for the AMS at all 3 sites (Fig. 2). However, clearer patterns are identified 


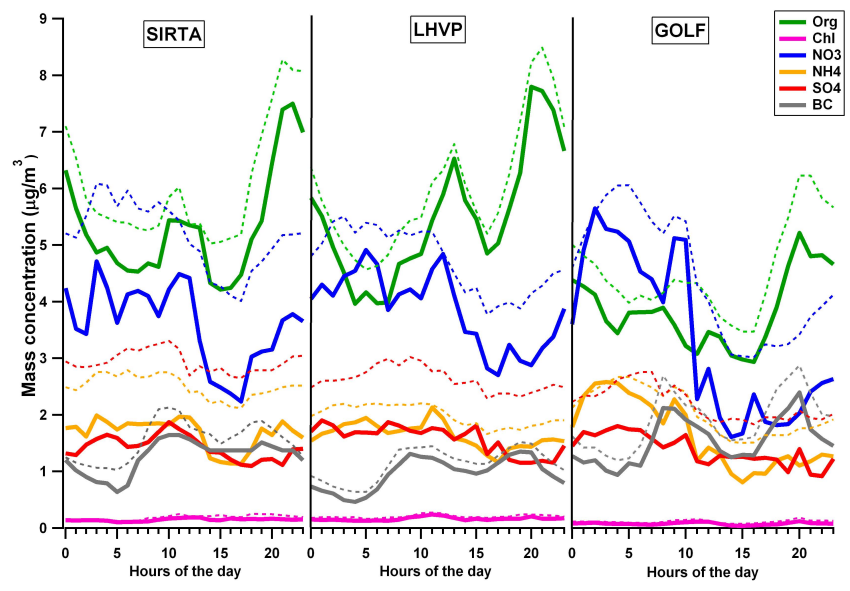

Fig. 2. Diurnal variation of organics, inorganics and black carbon in the Paris region (solid line $=$ median values, dashed line $=$ mean values).

at the city site (LHVP) due to its proximity to local emission sources, whereas meteorological factors and mixing during transport make these trends less pronounced at the urban background sites.

A weak daily pattern is seen for $\mathrm{NH}_{4}^{+}$and $\mathrm{SO}_{4}^{2-}$ due to the lower volatility of sulfates and their regional distribution, while temperature-regulated gas/particle partitioning is observed for particulate nitrate (higher concentration levels during the night and coldest hours of the day and decreasing concentration with increasing temperature). The organic species peak during the morning and evening rush hours but a large increase from late afternoon to late evening has also been identified at all 3 sites, due to secondary formation and biomass burning contribution (as described in Sect. 3.2.3). The LHVP station shows a lunch time peak due to cooking activities. These complex features in the organics daily pattern suggest contributions from multiple sources, formation mechanisms and/or influence of meteorological conditions.

\subsection{Investigation of organic aerosols sources}

\subsubsection{Summary of PMF results}

In this section, the investigation of the PMF solutions in terms of mass spectra, time series and correlations with external data is described. First, a general characterization of the sources is presented, followed by discussion of the specific solutions obtained for each measurement site. Figures 3 to 5 show the factor mass spectra and time series for the selected PMF solutions at each site. Further support for the selected PMF solutions is obtained by comparison of the factor mass spectra with preexisting reference spectra (DeCarlo et al., 2010; $\mathrm{Ng}$ et al., 2010; He et al., 2010) and factor time series with ancillary measurements of related species. Comparisons with reference mass spectra and tracer time series are presented below. Both primary (POA) and secondary (SOA) organic aerosol sources are identified, although the contribution of each source varies between sites.

Each identified source is characterized by specific significant masses in the organic mass spectra. Hydrocarbonlike organic aerosol (HOA), biomass burning OA (BBOA) and cooking-related organic aerosol (COA) are classified as POA. The HOA profile is dominated by peaks characteristic of aliphatic hydrocarbons, including $m / z 27\left(\mathrm{C}_{2} \mathrm{H}_{3}^{+}\right), 41$ $\left(\mathrm{C}_{3} \mathrm{H}_{5}^{+}\right), 43\left(\mathrm{C}_{3} \mathrm{H}_{7}^{+}\right), 55\left(\mathrm{C}_{4} \mathrm{H}_{7}^{+}\right), 57\left(\mathrm{C}_{4} \mathrm{H}_{9}^{+}\right), 69\left(\mathrm{C}_{5} \mathrm{H}_{9}^{+}\right)$, $71\left(\mathrm{C}_{5} \mathrm{H}_{11}^{+}\right)$(Canagaratna et al., 2004; Aiken et al., 2009). The BBOA profile is characterized by higher contributions at masses $29\left(\mathrm{CHO}^{+}\right), 60\left(\mathrm{C}_{2} \mathrm{H}_{4} \mathrm{O}_{2}^{+}\right)$and $73\left(\mathrm{C}_{3} \mathrm{H}_{5} \mathrm{O}_{2}^{+}\right)$which are associated with fragmentation of sugars such as levoglucosan (Alfarra et al., 2007). Primary BBOA likely consists of monosaccharide derivatives from the pyrolysis of cellulose, with lesser contributions from straight-chain aliphatics, oxygenated compounds such as cellulose and lignin, and terpenoids. Levoglucosan is produced by cellulose pyrolysis and it is frequently used as a tracer for biomass burning emissions (Simoneit et al., 1999). However, recent studies have shown that levoglucosan is not completely stable in the atmosphere due to oxidation (Hennigan et al., 2010). It has been also shown that the fraction of soluble potassium not related to sea salt can be associated to the combustion of biomass (Gilardoni et al., 2009; Sciare et al., 2011), therefore potassium from the PILS is included as a biomass burning tracer species in Fig. 3. The COA profile is similar to the HOA one, however high resolution spectra from literature suggest that it contains more oxidized species at the same nominal masses (masses $41\left(\mathrm{C}_{3} \mathrm{H}_{5}^{+}, \mathrm{C}_{2} \mathrm{HO}^{+}\right), 43\left(\mathrm{C}_{3} \mathrm{H}_{7}^{+}, \mathrm{C}_{2} \mathrm{H}_{3} \mathrm{O}^{+}\right)$, $55\left(\mathrm{C}_{4} \mathrm{H}_{7}^{+}, \mathrm{C}_{3} \mathrm{H}_{3} \mathrm{O}^{+}\right)$and $\left.57\left(\mathrm{C}_{4} \mathrm{H}_{9}^{+}, \mathrm{C}_{3} \mathrm{H}_{5} \mathrm{O}^{+}\right)\right)(\mathrm{He}$ et al., 2010; Mohr et al., 2012). At unit mass resolution, some specific patterns appear in the COA spectrum, where the ratios of some organic masses, such as org41 (organic mass at $m / z$ 41) to $\operatorname{org} 43$ (organic mass at $m / z$ 43) for COA and $\operatorname{org} 55$ (organic mass at $m / z 55$ ) to org57 (organic mass at $m / z$ 57) are higher for COA than for HOA. An elevated org55/org57 ratio has recently been shown to be a robust marker for COA in Barcelona (Mohr et al., 2012), as shown in Fig. SI-6.6.2.

Paris wintertime SOA mainly consists of a low-volatility fraction of the oxidized organic aerosols (OOA). This component is highly oxygenated, as evidenced by the large contribution from org44 $\left(\mathrm{CO}_{2}^{+}\right)$(Aiken et al., 2009). Additionally, a factor dominated by org 44 (indicating oxygenation) and oxygenated BBOA components has been resolved $\left(\mathrm{OOA}_{2}-\mathrm{BBOA}\right)$. The $\mathrm{OOA}_{2}$-BBOA profile is characterized by both the masses typical of biomass burning and literature spectra of semi-volatile OOA $\left(\mathrm{OOA}_{2}\right)$ spectra $\left(\operatorname{org} 29\left(\mathrm{CHO}^{+}\right), \operatorname{org} 43\left(\mathrm{C}_{2} \mathrm{H}_{3} \mathrm{O}^{+}\right)\right.$, org44 $\left(\mathrm{CO}_{2}^{+}\right)$, org60 $\left(\mathrm{C}_{2} \mathrm{H}_{4} \mathrm{O}_{2}^{+}\right)$(Alfarra et al., 2007). It is unclear whether this factor represents BBOA SOA, processed primary BBOA, or an atmospheric mixture of primary BBOA with OOA from another source. The $\mathrm{OOA}_{2}$-BBOA time series correlates with LHVP levoglucosan, supporting a biomass burning 


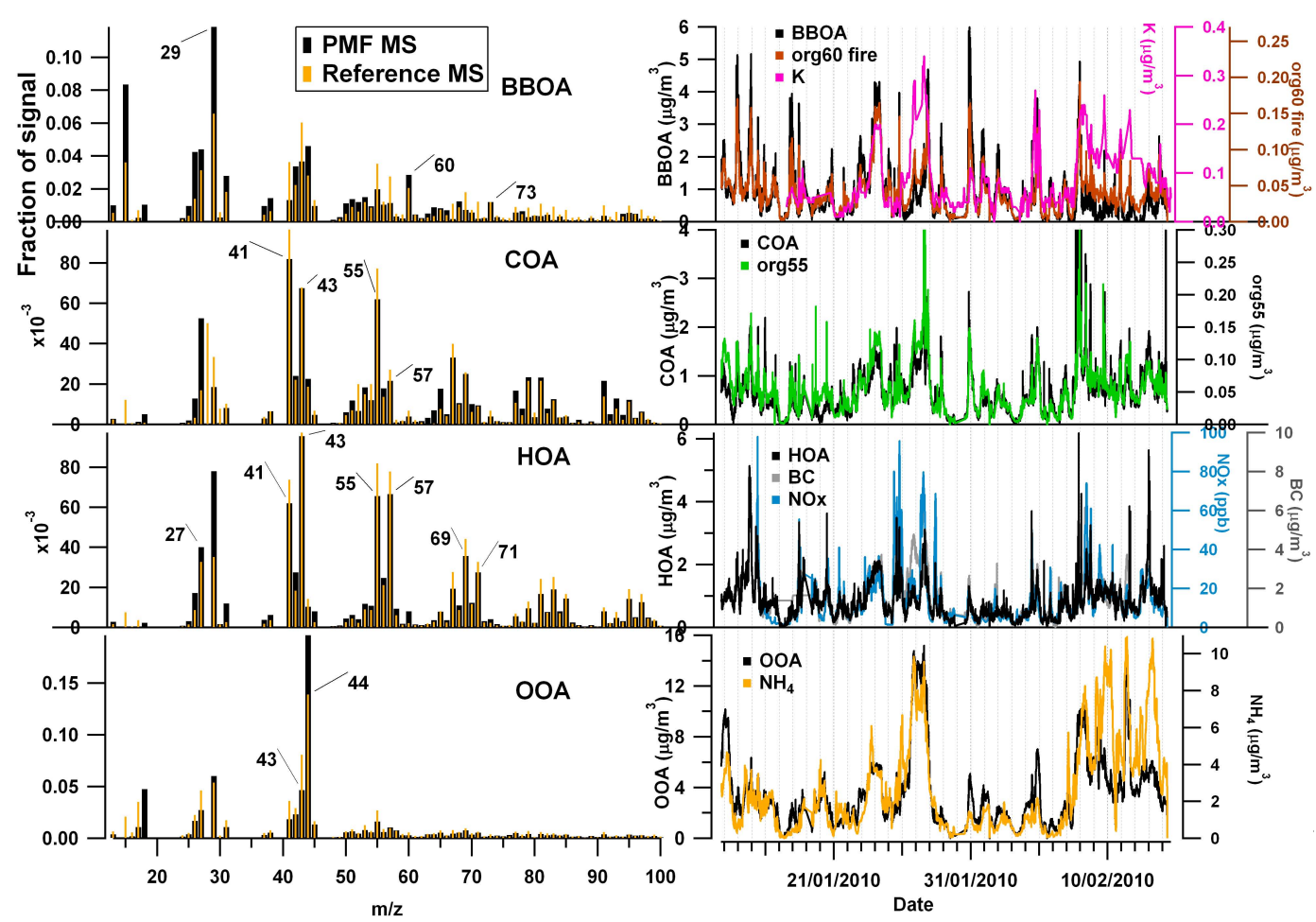

Fig. 3. PMF results: time series and mass spectral comparisons (SIRTA site). The COA reference spectrum is calculated as the mean of all cooking emissions spectra measured by He et al. (2010); other reference spectra are provided by $\mathrm{Ng}$ et al. (2010).

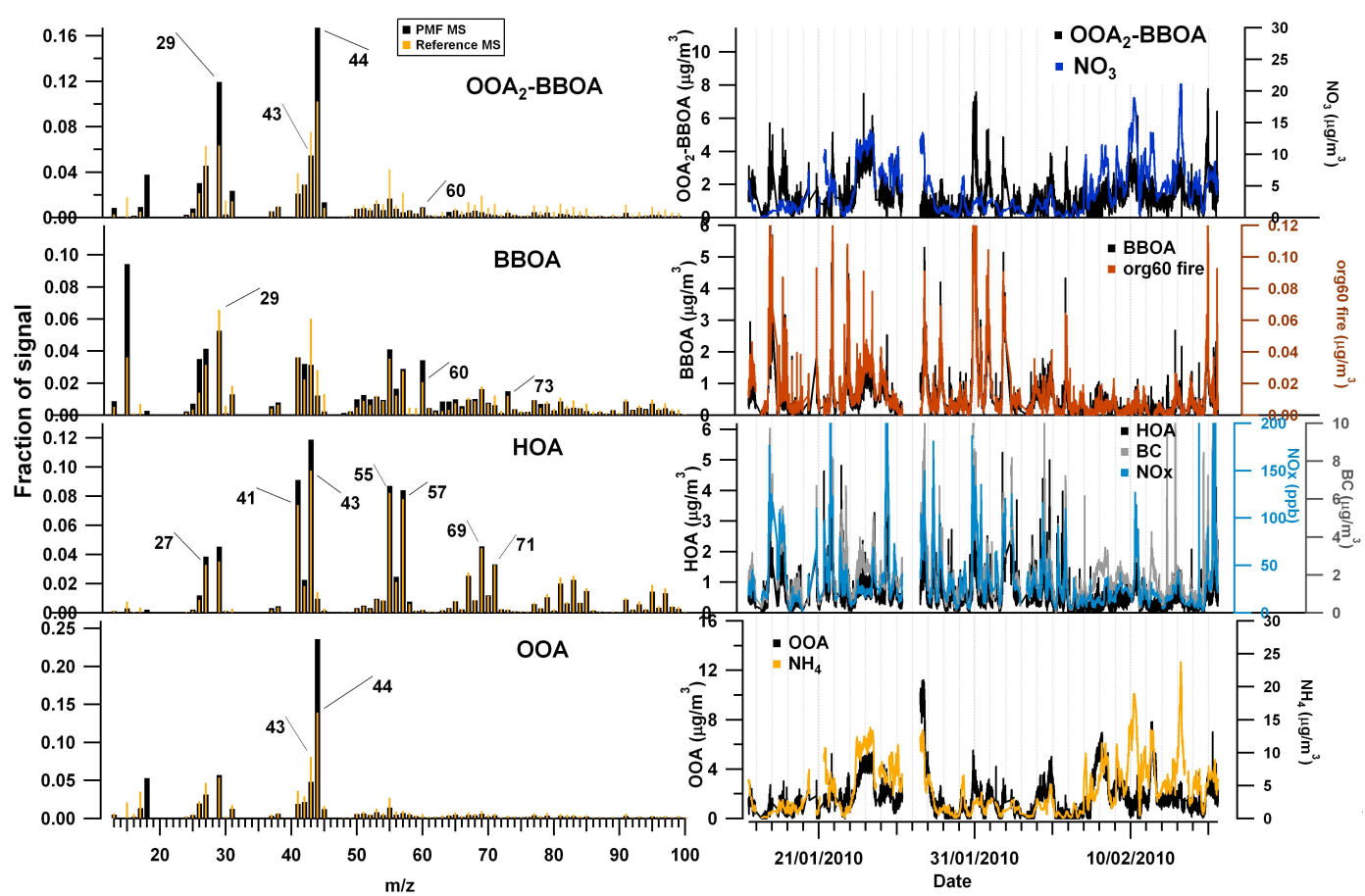

Fig. 4. PMF results: time series and mass spectral comparisons (GOLF site). Reference spectra are provided by Ng et al. (2010) for BBOA, HOA, and COA, and by DeCarlo et al. (2010) for $\mathrm{OOA}_{2}$-BBOA. 


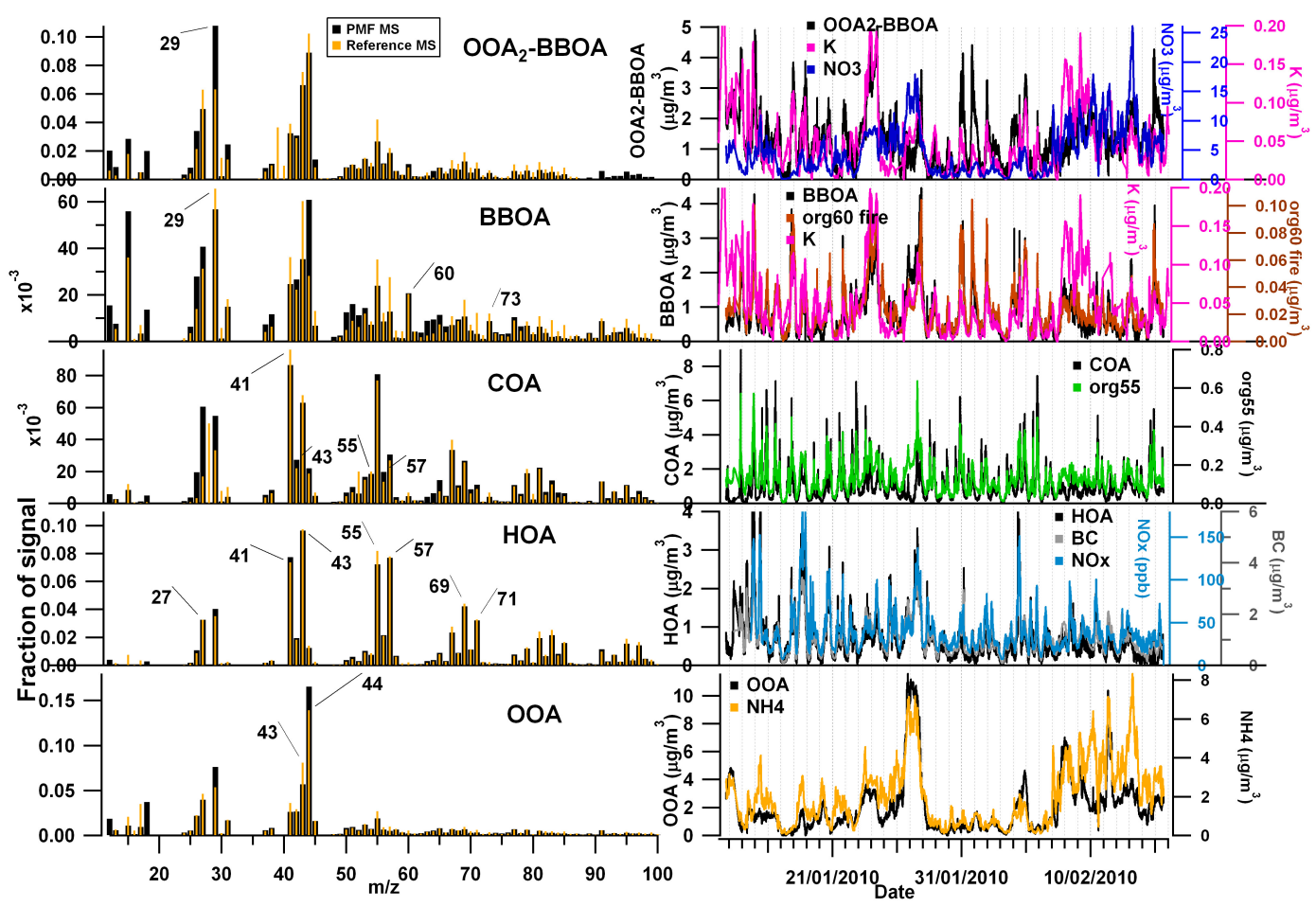

Fig. 5. PMF results: time series and mass spectral comparisons (LHVP site). The COA reference spectrum is calculated as the mean of all cooking emissions spectra measured by $\mathrm{He}$ et al. (2010), and the $\mathrm{OOA}_{2}$-BBOA spectra is from DeCarlo et al. (2010), and other reference spectra are taken from $\mathrm{Ng}$ et al. (2010).

influence (Fig. 6). Note that the $\mathrm{OOA}_{2}-\mathrm{BBOA}$ spectrum is compared with the BBOA SOA source identified by DeCarlo et al. (2010) for airborne measurements during the MILAGRO campaign. The higher organic contribution at mass 44 and the lower fractional signal at larger masses compared to primary wood burning emissions might indicate the presence of secondary products in this factor. In addition, the $\mathrm{OOA}_{2}$ BBOA mass spectrum presents more similarities with the aged BBOA than primary woodstove emissions (Grieshop et al., 2009). Additional source apportionment analysis performed combining gas (PTRMS) and particle phase (AMS) measurements for the LHVP site allowed a clearer discrimination of a pure BBOA source and a secondary semi-volatile OOA (SV-OOA) (Crippa et al., 2013a). The correlation coefficients of the obtained source profiles at the 3 sites with the reference ones are summarized in Table 1.

The interpretation of each source is supported by the comparison of the PMF factor time series with independent measurements performed during the campaign at the 3 stations.

The $R^{2}$ values for $\mathrm{NH}_{4}^{+}, \mathrm{NO}_{3}^{-}$and $\mathrm{SO}_{4}^{2-}$ with respect of to OOA component are $0.64,0.53$ and 0.65 for the LHVP site, $0.36,0.32$ and 0.21 for the GOLF site and $0.67,0.53$ and 0.63 for the SIRTA site, respectively. The lower $R^{2}$ value obtained for the GOLF site can be partially explained by a better correlation of the OOA time series during the last period of the campaign (after 10 February) with $\mathrm{SO}_{4}^{2-}$ than with $\mathrm{NH}_{4}^{+}$due to the aged air masses and by the fact that the first high concentration event (26-28 January) was missed at this site.

The HOA time series correlate with traffic related tracers such as $\mathrm{BC}$ and $\mathrm{NO}_{\mathrm{x}}\left(R^{2}=0.71, R^{2}=0.64, R^{2}=0.48\right.$ with $\mathrm{BC}$ and $R^{2}=0.76,0.66,0.50$ with $\mathrm{NO}_{\mathrm{x}}$, for the LHVP, GOLF and SIRTA sites respectively). For COA, a high correlation with one of its characteristic masses, org55, is found $\left(R^{2}=0.59, R^{2}=0.72\right.$ for the LHVP and SIRTA sites, respectively). The org60 signal above ambient background is assumed to derive entirely from fires (wildfires, biomass burning, etc.). Typical ambient backgrounds for $f_{60}$ (defined as org60 divided by the total organic signal) are approximately 0.003 (e.g DeCarlo et al., 2008; Aiken et al., 2009; Docherty et al., 2008). $R^{2}$ values for BBOA vs. org60 are $0.85,0.89$ and 0.86 for the LHVP, GOLF and SIRTA sites, respectively. Figure SI-6.6.1 shows the correlation between the fractional BBOA contribution and $f_{60}$. An additional comparison was performed between BBOA and levoglucosan concentrations from 12-h filters measurements obtained at the SIRTA and LHVP sites $\left(R^{2}=0.81\right.$ and $R^{2}=0.69$, respectively), showing a high correlation with both the averaged PMF biomass burning and $\mathrm{OOA}_{2}-\mathrm{BBOA}$ components (Fig. 6). A higher correlation with the levoglucosan measurements was obtained when considering the sum of the BBOA and $\mathrm{OOA}_{2}$-BBOA PMF factors for the LHVP site $\left(R^{2}=0.83\right)$ than for either factor considered separately 

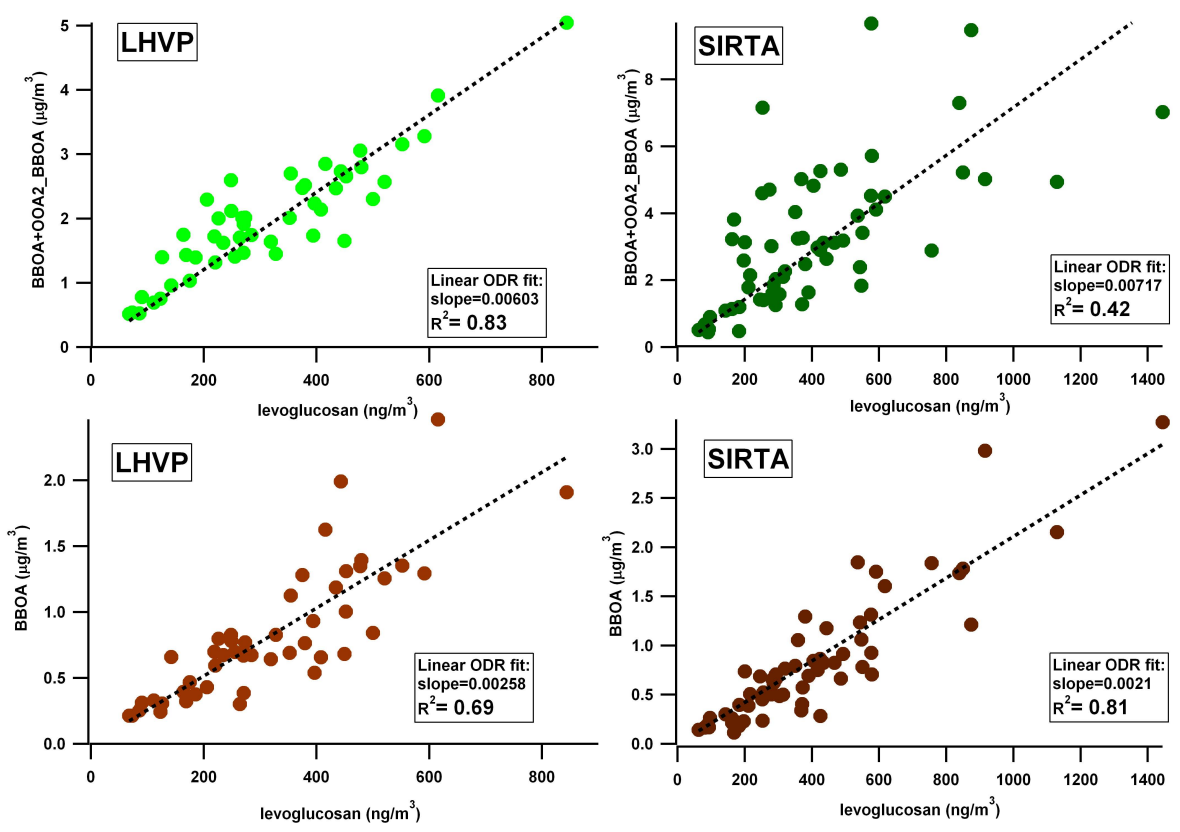

Fig. 6. Comparison of biomass burning-related PMF factors and filter measurements of levoglucosan at the LHVP and SIRTA sites.

Table 1. Comparison between reference spectra and PMF factors. The COA reference spectra are calculated as the mean of all cooking emissions spectra measured by He et al. (2010); other reference spectra are provided by $\mathrm{Ng}$ et al. (2010) and by DeCarlo et al. (2010) for the $\mathrm{OOA}_{2}$-BBOA spectrum.

\begin{tabular}{lccccc}
\hline \multicolumn{5}{c}{ Reference spectra $\left(R^{2}\right)$} \\
\hline PMF factors & OOA & HOA & BBOA & COA & OOA $_{2}$-BBOA \\
\hline \multicolumn{5}{c}{ GOLF } \\
\hline OOA & 0.88 & 0.08 & 0.24 & 0.17 & 0.65 \\
HOA & 0.22 & 0.98 & 0.64 & 0.76 & 0.40 \\
BBOA & 0.26 & 0.36 & 0.69 & 0.37 & 0.29 \\
OOA $_{2}$-BBOA & 0.85 & 0.15 & 0.47 & 0.18 & 0.77 \\
\hline \multicolumn{5}{c}{ LHVP } \\
\hline OOA & 0.96 & 0.08 & 0.45 & 0.26 & 0.81 \\
HOA & 0.22 & 0.98 & 0.62 & 0.76 & 0.40 \\
BBOA & 0.71 & 0.30 & 0.76 & 0.41 & 0.71 \\
OOA 2 -BBOA & 0.80 & 0.36 & 0.80 & 0.38 & 0.84 \\
COA & 0.34 & 0.72 & 0.71 & 0.86 & 0.54 \\
\hline \multicolumn{5}{c}{ SIRTA } \\
\hline OOA & 0.92 & 0.12 & 0.36 & 0.21 & 0.44 \\
HOA & 0.30 & 0.90 & 0.79 & 0.71 & 0.49 \\
BBOA & 0.48 & 0.18 & 0.71 & 0.24 & 0.44 \\
COA & 0.29 & 0.77 & 0.58 & 0.86 & 0.47 \\
\hline
\end{tabular}

$\left(R^{2}=0.69\right)$. This suggests that $\mathrm{OOA}_{2}-\mathrm{BBOA}$ represents an atmospheric mixture of primary BBOA and background OOA. From the filter measurements, the organic carbon to levoglucosan ratio is on average $10.86 \pm 5.48$ for the SIRTA site and $16.03 \pm 7.23$ for the LHVP one. These values are comparable to the ones measured by Puxbaum et al. (2007) over Europe, which range from 6 to 12.5. The BBOA-tolevoglucosan ratio is very low for both sites and on average equal to 2.58 for LHVP and 2.11 for SIRTA, suggesting that the BBOA alone does not present the total OA due to wood burning. When considering the sum of $\mathrm{OOA}_{2}-$ $\mathrm{BBOA}$ and $\mathrm{BBOA}$, the ratios with levoglucosan are 7.17 and 6.03 for the SIRTA and LHVP site, respectively. Although no $\mathrm{OOA}_{2}$-BBOA was separated at the SIRTA site (see Sect. 3.2), the five-factor PMF solution provided a split of the OOA factor containing a non-negligible fraction of $\mathrm{m} / \mathrm{z} 60$ which was included in the calculation of the BBOAto-levoglucosan ratio (see Sect. 3.2.2). However, the $R^{2}$ between the sum of the biomass burning related factors and levoglucosan decreases compared to the one obtained using only the BBOA factor. This might be partially explained by the poorly split OOA/levoglucosan correlation during two high pollution events where the split OOA factor is strongly affected by aged SOA. The evaluated BBOA-to-levoglucosan ratios are comparable to those observed in several ambient studies (Szidat et al., 2009) but slightly lower than the value of 10.3 (OM biomass burning/levoglucosan) obtained for $\mathrm{PM}_{2.5}$ by Sciare et al. (2011) at the SIRTA site in winter 2009. However, higher values of levoglucosan contributions to biomass burning compared to literature studies have also been found by Elsasser et al. (2012) during ambient measurements in Augsburg, Germany.

To validate the cooking source identified at the LHVP and SIRTA sites, correlations with fatty acids from $\mathrm{PM}_{2.5}$ filter measurements were performed. Figure 7 shows the scatter plot of the COA factors vs. the stearic acid concentrations; 


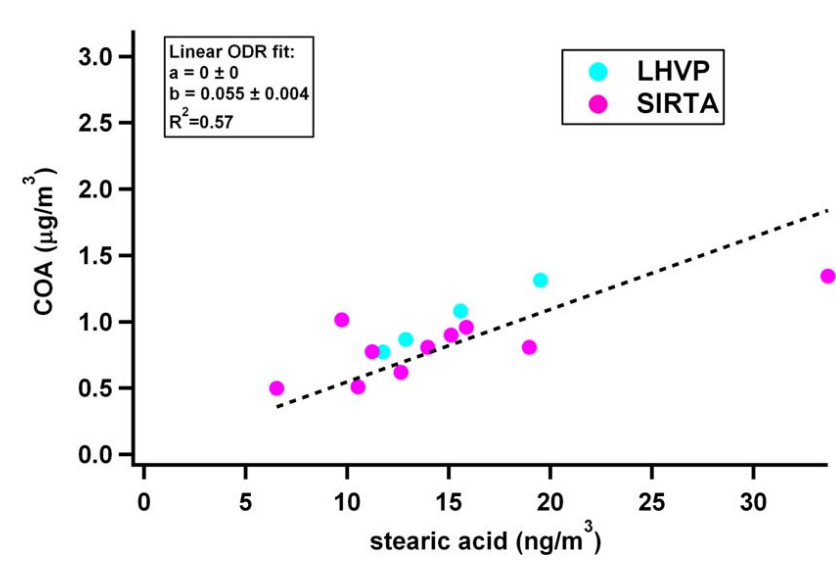

Fig. 7. Comparison of stearic acid (GC-MS) and COA (PMF) concentrations.

the linear correlation provided an $R^{2}$ of 0.57 and a COA-to-stearic acid ratio of 55. Similar results have been observed by Robinson et al. (2006) where a COA-to-stearic acid ratio of 53 was obtained using chemical mass balance and stearic acid measurements.

\subsubsection{Comparison of PMF results between sites}

A general overview of the PMF results was presented above; here we focus on details of the solutions that are unique to the specific sites. For the LHVP station three POA sources (HOA, BBOA and COA) and two SOA factors (OOA, $\mathrm{OOA}_{2}-\mathrm{BBOA}$ ) were identified. The LHVP station is located in the Paris centre and is heavily influenced by primary emission sources (traffic, residential heating, restaurants, etc.). Therefore the separation of these components and of the oxidized fractions by PMF was possible due to the differing temporal variation of these sources. For the urban background sites (SIRTA and GOLF), the organic source apportionment provided slightly different solutions, possibly because the distance from primary sources made them harder to distinguish. Such an effect of distance and transport time has previously been observed in PMF analyses (Lanz et al., 2008).

For the SIRTA station a five-factor PMF was selected and reduced to four by combination of two closely related factors to form a single OOA. The resulting four factors consisted of three POA sources (HOA, BBOA, COA) and one SOA source (OOA). This was required as lower order solutions were unable to resolve the COA factor (see SI-6.2). The two combined OOA spectra are very similar except for a different contribution to org60 $\left(5.5 \times 10^{-4} \%\right.$ and $\left.0.5 \%\right)$, the latter of which is only slightly above background levels $(0.3 \%)$ (Cubison et al., 2011). This org60 could be related to the oxidation and aging of the primary wood burning emissions or atmospheric and/or mathematical mixing of sources. Since no clear separation of the biomass burning and pure OOA contributions was possible, the SIRTA OOA time se-

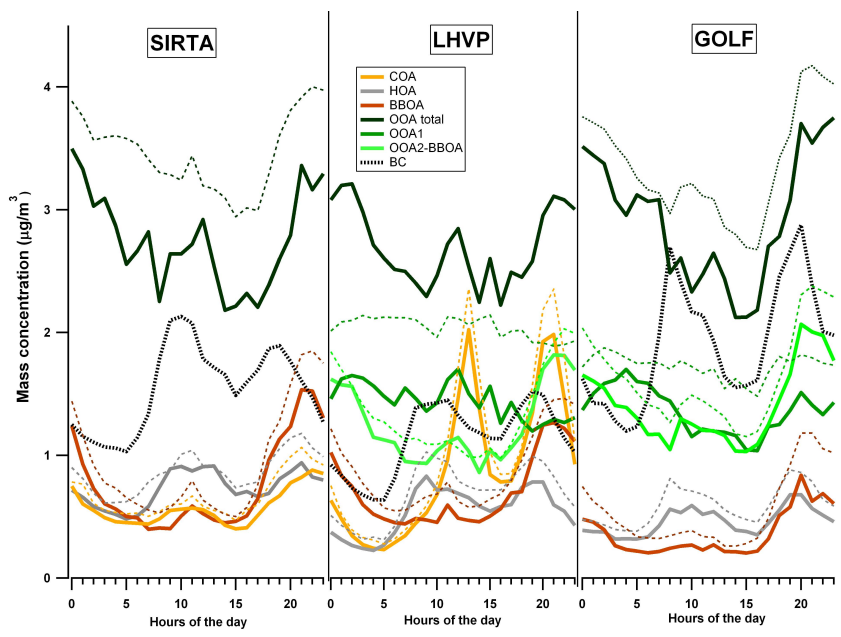

Fig. 8. Diurnal patterns of the PMF factors (solid line = median values, dashed line $=$ mean values). For comparison, the OOA total, which represents the sum of $\mathrm{OOA}_{1}$ and $\mathrm{OOA}_{2}-\mathrm{BBOA}$ when these two sources were identified separately by PMF, is shown.

ries are taken as the sum of the two OOA factors, while the mass spectrum is calculated as their mass-weighted average.

The GOLF site yielded only two POA factors (HOA and $\mathrm{BBOA}$ ), while two SOA factors (OOA and $\mathrm{OOA}_{2}-\mathrm{BBOA}$ ) were resolved. Here the $\mathrm{OOA}_{2}$-BBOA component is a recombination of two split factors within the 5-factor PMF solution; the higher-factor solution (5 factors instead of 4) was selected for its improved differentiation and interpretation of the factor mass spectra (see Sect. 6.2 of the Supplement). Factor recombination followed the same method as previously explained for SIRTA.

\subsubsection{PMF factors diurnal patterns}

The absolute contributions from the PMF factors vary with time of day, as shown in Fig. 8. The daily pattern of HOA follows BC and is characterized by the strong peaks during the morning and evening rush hours, suggesting an important traffic influence. COA peaks at 13:00 $\mathrm{h}$ and 20:0021:00 h, consistent with meal times. BBOA increases significantly from late in the afternoon until the night, probably mainly due to wood combustion used for domestic heating. The OOA pattern is relatively independent of the time of day. In contrast, $\mathrm{OOA}_{2}-\mathrm{BBOA}$ increases significantly from the late afternoon through the night, similar to BBOA. As mentioned before, the diurnal patterns are more distinct for the urban core site (LHVP) because of the mixing and aging processes occurring during transport to SIRTA and GOLF.

On average the total oxidized fraction of OA accounts for more than $50 \%$ (57\%, $58 \%$ and $74 \%$ for the LHVP, SIRTA and GOLF sites, respectively), highlighting the importance of regional SOA even in downtown Paris. The HOA contribution ranges on average from $11 \%$ to $13 \%$ (16-19\% during 
the morning rush hours) and the BBOA contribution from $13 \%$ to $16 \%$ (17-19\% during the evening peak). The COA fraction contributes on average $11 \%$ at SIRTA and $17 \%$ at LHVP to the total organic mass, but reaches $35 \%$ during the lunch hour for LHVP. Cooking has previously been recognized to contribute significantly to the total organic mass in several cities, e.g. London and Manchester (Allan et al., 2010), Barcelona (Mohr et al., 2012), Zurich (Lanz et al., 2007), Toronto (Slowik et al., 2010), Beijing (Huang et al., 2010; Sun et al., 2010), New York (Sun et al., 2011) and Fresno (Ge et al., 2012).

An alternative method of estimating the presence of COA based on mass spectral markers rather than a resolved COA PMF factor was developed by Mohr et al. (2012). Figure 9 shows this analysis for the LHVP site. Here the primary organic mass fractions at $\mathrm{m} / z 55$ and $57\left(f_{55, \mathrm{OOAsub}}\right.$ and $f_{57, \mathrm{OOAsub}}$, with contributions from OOA and $\mathrm{OOA}_{2}-\mathrm{BBOA}$ subtracted) are shown colored by the time of day, with the space bounded on the left/top side by the literature values for "pure" cooking factors and on the right/bottom by literature values for HOA. The points within the "pure" cooking and traffic lines represent the mixture of HOA, COA, BBOA and all the primary sources contributing to the organic composition. Similar to Fig. 8, Fig. 9 clearly shows the different temporal variation in HOA and COA spectral markers (organic fragments $f_{55}$ and $f_{57}$ ). The $f_{55} / f_{57}$ ratio peaks around midday and evening hours, when cooking sources are stronger. An appropriate estimation of the cooking contribution for the GOLF site using the approach by Mohr et al. (2012) could not be performed due to the non-negligible contribution of biomass burning in the Parisian area, because biomass burning contributions to org44, org55, and org57 are not accounted for in the Mohr et al. (2012) parameterization. A coherent prediction of the COA factor at SIRTA was obtained when inputs for the parameterization were obtained from the SIRTA PMF solution. However, COA was underestimated when SIRTA data was used in conjunction with LHVP-derived coefficients. Therefore the uncertainty and/or source variability associated with the Mohr et al. (2012) parameterization must be accounted for in estimating cooking source contributions at a given site.

\subsection{Black carbon apportionment}

Here we present the results of the BC apportionment based on the wavelength-dependent light absorption model (Sandradewi et al., 2008) described in Sect. 2.3.2.

Black carbon is produced exclusively by combustion processes. As a result its major sources include both fossil fuel combustion (mainly traffic) and wood burning (Bond et al., 2004). BC from these sources can be apportioned using the wavelength dependent light absorption model (Sandradewi et al., 2008) described in Sect. 2.2.3. Unique POA factors corresponding to these processes were also resolved using PMF: HOA is related to traffic and BBOA to wood burning

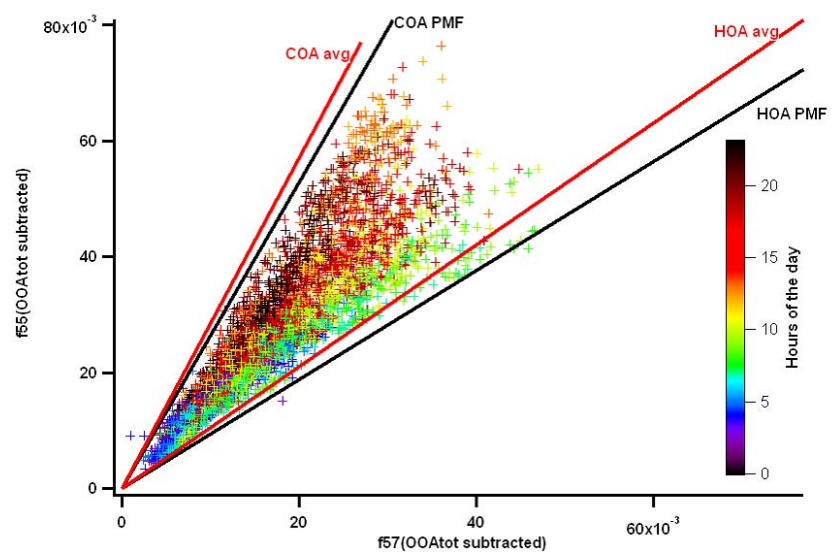

Fig. 9. Mass fraction of $m / z 55$ and $57\left(f_{55}\right.$ and $\left.f_{57}\right)$ for primary organics at the LHVP site. Reference lines for pure COA and HOA (defined as $\mathrm{COA}_{\mathrm{avg}}$ and $\mathrm{HOA}_{\mathrm{avg}}$, respectively) are shown.

emissions. Comparison of these OA factors with the BC optical apportionment results provides additional information on the contribution of these emission sources to a toxic and carcinogenic component of particulate matter (McCreanor et al., 2007) and further supports the interpretation of each method. The time series of corresponding factors from each apportionment method are shown in Fig. 10, and the mass concentrations of the corresponding $\mathrm{OA}$ and $\mathrm{BC}$ factors are plotted in Fig. 11.

Figures 10 and 11 present the results obtained using $\alpha_{\mathrm{tr}}=$ 1 and $\alpha_{\mathrm{bb}}=2$. The average ratios of $\mathrm{HOA}$ to $\mathrm{BC}_{\mathrm{tr}}$ found from the slopes in Fig. 11 are 0.37 (intercept $=0.33$ ) and 0.61 (intercept $=-0.12$ ) for the two sites, and the $\mathrm{BBOA}$ to $\mathrm{BC}_{\mathrm{bb}}$ ratios are 3.16 (intercept $=0.11$ ) and 3.62 (intercept $=-0.12$ ) both ratios are thus quite consistent between the two stations. Considering the SIRTA case, a positive intercept is found both for the $\mathrm{HOA}$ vs. $\mathrm{BC}_{\mathrm{tr}}$ and $\mathrm{BBOA}$ vs. $\mathrm{BC}_{\mathrm{bb}}$ comparison (0.33 and 0.106, respectively), representing an underestimation of $\mathrm{BC}_{\mathrm{tr}}$ and $\mathrm{BC}_{\mathrm{bb}}$ for this site. For the LHVP case the opposite situation is observed: negative intercepts are found for the HOA and BBOA vs. the corresponding $\mathrm{BC}$ fractions $(-0.12$ for both sources), meaning that the $\mathrm{BC}$ associated to these two sources is slightly overestimated. The observed $\mathrm{HOA}$ to $\mathrm{BC}_{\text {tr }}$ ratio is smaller than the values reported for tunnel measurements at low OA concentrations (Chirico et al., 2011) because of different measurement conditions (lower temperatures during wintertime), in addition, different vehicles fleets and in urban areas stop-and-go traffic might be different from constant speed driving in a tunnel. For comparison smog chamber experiments revealed an average OM/BC ratio for primary diesel car emissions of $0.28 \pm 0.15$ (Chirico et al., 2010). Smog chamber studies (Heringa et al., 2011) indicate high variability of the $\mathrm{BBOA}$ to $\mathrm{BC}_{\mathrm{bb}}$ ratio depending on the burning conditions, the type of wood used etc. However, the ratios found in the present study are comparable to 

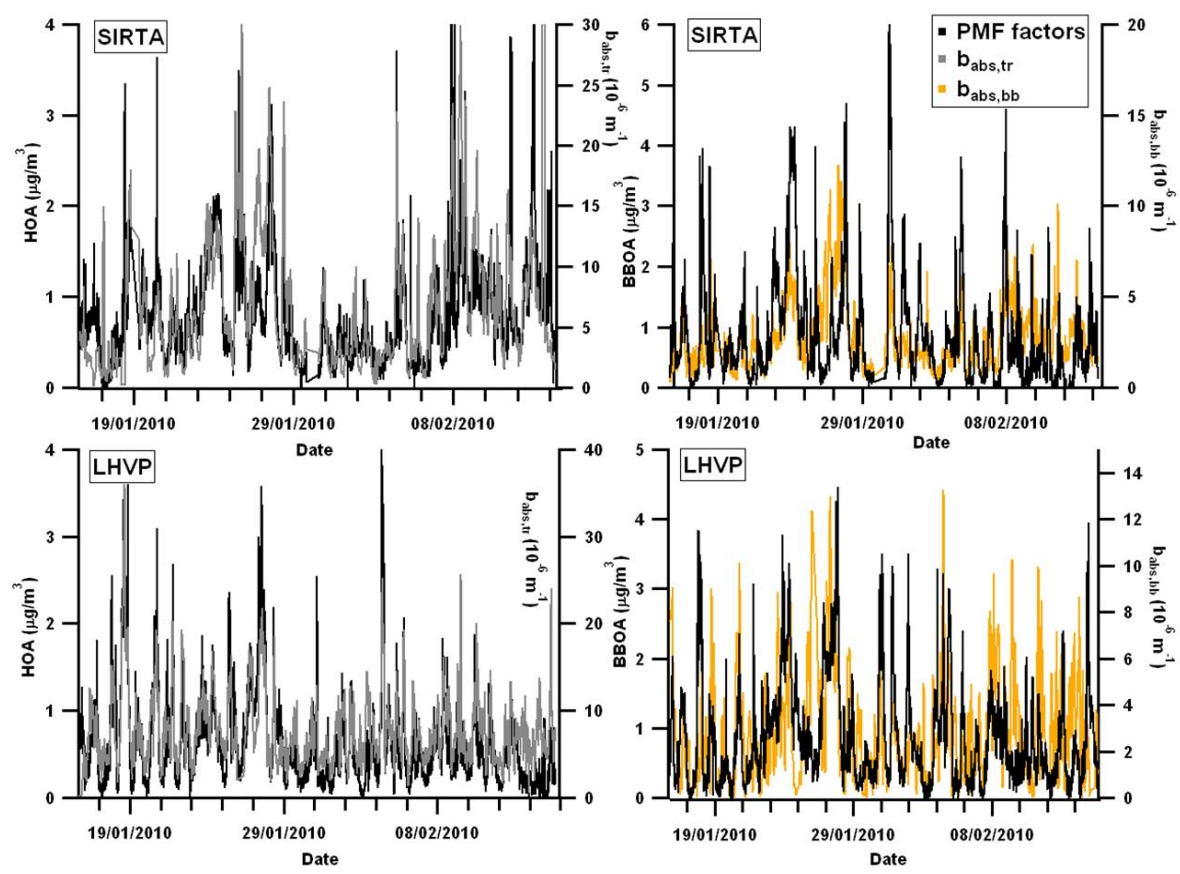

Fig. 10. Time series comparison of AMS and BC factors related to traffic and wood burning at the SIRTA and LHVP sites.

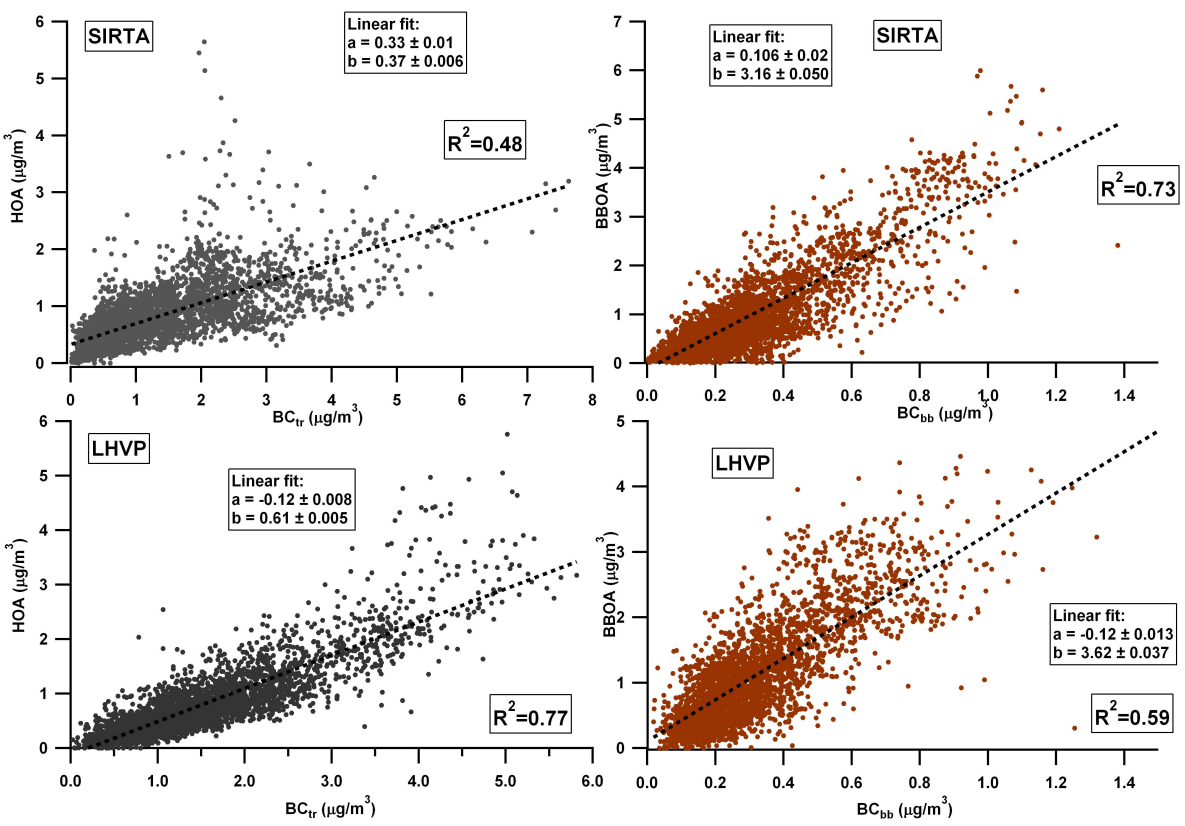

Fig. 11. Comparison of HOA and BBOA apportionment using PMF and the aethalometer methods. Orthogonal distance regression provides slopes of 0.55 and 0.56 for the $\mathrm{HOA}-\mathrm{BC}_{\mathrm{tr}}$ plots and 3.83-3.9 for the $\mathrm{BBOA}-\mathrm{BC}_{\mathrm{bb}}$ ones.

those found from other ambient measurements (Szidat et al., 2006).

On average traffic contributes $76 \%$ and $80 \%$ to the total BC mass at SIRTA and LHVP, respectively, while the combustion of biomass is a minor source of BC (24\% and $20 \%)$.
The good agreement between the $\mathrm{HOA}$ and $\mathrm{BC}_{\mathrm{tr}}$ supports the individual apportionment strategies and validates the correct identification and separation of the cooking factor from HOA for both LHVP and SIRTA. 


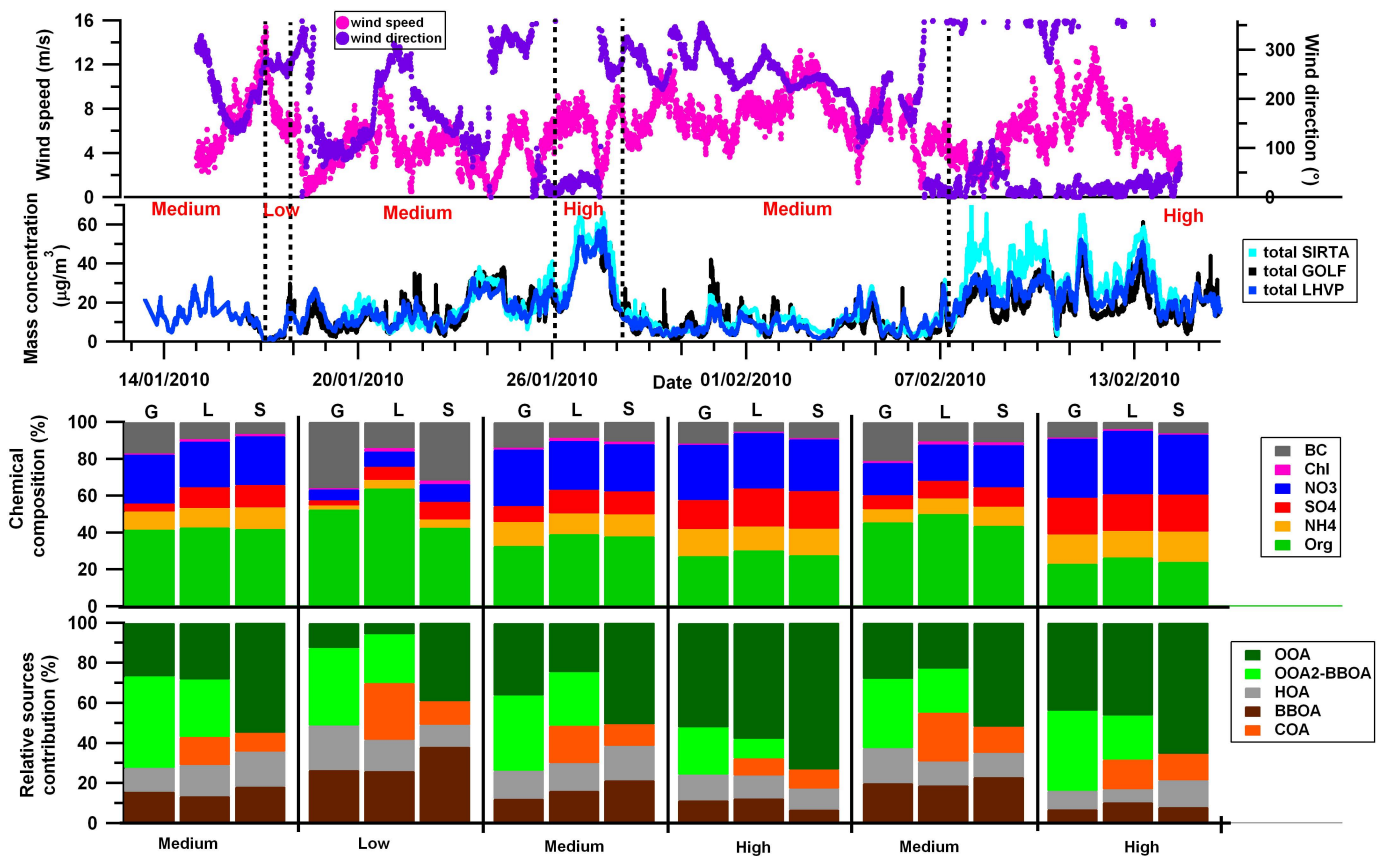

Fig. 12. Temporal variation of the chemical composition and organic source apportionment for different wind sectors and mass concentrations ( $\mathrm{G}=$ GOLF site, $\mathrm{L}=$ LHVP site, $\mathrm{S}=$ SIRTA site). The total mass is the sum of the AMS species and BC measurements (blue lines).

\subsection{Relative contribution of regional and local sources}

The top panel of Fig. 12 shows the temporal variation of the total AMS and black carbon mass concentrations for all the sites, together with the corresponding wind speed and wind direction measured at $100 \mathrm{~m}$ a.g.l. at SIRTA. Using the wind direction and mass concentration data, the entire campaign was separated into 6 time periods characterized by different chemical composition and organics apportionment. These periods are designated in the top panel of Fig. 12, and the bar graphs in the lower panels show the overall and organic composition. For the low concentration event on 17 January 2010, organics and black carbon are dominant, suggesting fresh emissions in agreement with similar observations reported at LHVP during springtime (Sciare et al., 2010). The three periods defined as "medium" are characterized by around $20 \mu \mathrm{g} \mathrm{m}^{-3}$ of $\mathrm{PM}_{1}$ mass concentration and the aerosol chemical composition is comparable with the average values for the whole campaign. During the two high-level events identified in the middle and in the end of the campaign, air arrives from the northeast and the SIRTA site is downwind of Paris. Despite of this, concentrations at SIRTA are only slightly higher than at the other two sites, indicating the stronger effect of air masses from regional and long-range transport relative to the Paris plume. The influence of the transported (aged) air masses can be seen in higher fractions of $\mathrm{NO}_{3}^{-}, \mathrm{SO}_{4}^{2-}$ and $\mathrm{NH}_{4}^{+}$(secondary inorganic aerosols) compared to organics and also in the major contribution of SOA (50-70\%) compared to the organic primary sources.
Another important feature of Fig. 12 appears in the lower bar graph, where the OA source apportionment is classified according to meteorology, concentration, and air mass trajectory. During the clean period (labeled "low") the air masses come from the ocean in contrast to the medium and high pollution events (see SI-8). For the low pollution periods, the organics are mainly affected by local primary emission sources and less by secondary formation due to the wet deposition of all the accumulated and oxidized pollutants by a rain event on the night of the 16th. In contrast, the two high pollution events are dominated by SOA (50-70\% of the total organic mass) compared to the primary sources, suggesting more processed air.

The characteristics of these high/low concentration periods suggest that the aerosol composition for high concentrations within the Paris megacity is in fact heavily influenced by regional aerosol sources. Further support for this finding is seen in the rather uniform temporal variation of the aerosol chemical composition measured by the AMS among the three sites (see Fig. 1). An analogous comparison has been performed in terms of PMF results for both the factor mass spectra and time series (see Fig. SI-6.7.1). The identified PMF factors have similar mass spectra at all three Paris sites, with the exception of $m / z 15$ and 29 for BBOA and $m / z, 44$ for OOA, for which the differences are probably associated with differences in fragmentation and/or thermal decomposition among the AMS instruments (as discussed in Sect. SI-3). Similar to the inorganic species, the OOA time series are comparable at the three sites, suggesting 
that regional SOA production dominates over sources within the urban core. In contrast, the contribution of local emissions affects the variation of the primary sources (mainly HOA and COA), whereas local biomass burning spikes can be seen in addition to the wood burning background. In addition, Fig. SI-5.1 shows that the identified organic sources at the three sites are grouped in different regions of the triangular space defined by $\mathrm{Ng}$ et al. (2010). Some of the differences within each group of sources are probably due to the deployment of different types of instruments (e.g. C-ToF vs HR-ToF-AMS), different ion transmission and fragmentation etc.

To assess the impact of regional and local sources among the sites, a linear correlation between the time series of each PMF factor at the two urban background stations (SIRTA and GOLF) and the city site (LHVP) was performed using the orthogonal distance regression method. As expected the OOA values measured at the urban background locations correlate very well with LHVP (slope of 1.1 with $R^{2}$ equal to 0.89 , and slope of 0.97 with $R^{2}$ equal to 0.73 for the SIRTA and GOLF site, respectively). The linear regression applied to the BBOA components resulted in slopes of 1.15 and 0.86 for the SIRTA $\left(R^{2}=0.53\right)$ and GOLF sites $\left(R^{2}=0.49\right)$, respectively, indicating both background contributions and local emissions for biomass burning OA. However, the influence of primary local emissions can be found especially in the HOA time series, where the SIRTA vs. LHVP slope is 1.07 (with $R^{2}=0.38$ ) and the GOLF vs. LHVP slope is 1.07 $\left(R^{2}=0.31\right)$. Finally the cooking contribution shows clear local features, and the correlation between the COA time series of SIRTA and LHVP is very low (slope equal to 0.52 and $R^{2}=0.04$ ). Further evidence for the regional influences on Paris aerosol is provided by a comparison between the SIRTA and GOLF sites (urban background) with a remote rural site located $58 \mathrm{~km}$ east/northeast from the center of Paris. Aethalometer measurements at this site do not show significant differences from the SIRTA BC levels (see SI-7), indicating that the GOLF and SIRTA sites can be considered as urban background locations, and are far enough from the Paris megacity to assess its effects on the surrounding areas. However the surprisingly homogeneous distribution of the $\mathrm{BC}$ and the other aerosol species concentrations over the Paris area support the significant finding that Paris has a very low impact on the air quality of its surroundings. As already mentioned, measurements outside the Paris metropolitan area have been performed by two mobile laboratories; the detailed discussion of those results is beyond the scope of this work and will be addressed in companion papers (Von der Weiden-Reinmüller, 2013).

\section{Conclusions}

To assess the effect of a post-industrial megacity on regional air quality, measurements of submicron aerosol composition were performed during winter 2010 in the Paris metropolitan area, including three stationary measurement sites and two mobile laboratories. Here we discuss the stationary measurements, covering a domain of $\sim 40 \mathrm{~km}$ around Paris. The aerosol non-refractory composition and black carbon content were determined by aerosol mass spectrometer (AMS) and aethalometer measurements, respectively. AMS instruments were deployed at one site in the urban core and at two suburban background sites, while aethalometers were deployed in the urban core and at one suburban background site. The aerosol composition was similar at all three sites, with mean concentrations ranging from $30-36 \%$ organics, $28-29 \%$ nitrate, $12-14 \%$ ammonium, $14-16 \%$ sulfate, $0.8-1.2 \%$ chloride and $7-13 \%$ black carbon. The homogeneity of the particle composition and highly correlated time series across the three sites suggest a dominating influence of regional factors on Paris air quality during the MEGAPOLI campaign and a surprisingly minor influence of the Paris megacity on its surroundings in agreement with previous studies (Gros et al., 2011; Sciare et al., 2010).

The surprisingly low impact of Paris on its surroundings can be seen also in the reduced role of local sources which affect mainly the primary emissions and the significant contribution of specific urban sources, such as cooking, only in the core of the city.

Organic source apportionment using the PMF technique indicates a dominant contribution from secondary organic aerosol (57-74\%, depending on the site), with the major primary emissions sources consisting of traffic, biomass burning, and cooking emissions. While lower on average than the secondary sources, these primary emissions exhibit strong diurnal cycles and can become significant aerosol sources during peak hours. For example, the cooking factor contributes up to $35 \%$ of the total organic mass during lunch hours. Black carbon was apportioned to traffic and biomass burning sources using the wavelength dependence of light absorption by black carbon, which varies based on the source. A comparison of the organic factors from traffic and biomass burning with their corresponding black carbon factors shows very good agreement, supporting the individual apportionment techniques, and providing further evidence of the major role of such sources on PM composition in the region of Paris.

\section{Supplementary material related to this article is available online at: http://www.atmos-chem-phys.net/13/ 961/2013/acp-13-961-2013-supplement.pdf.}


Acknowledgements. This research in the context of the MEGAPOLI project is mainly financially supported by the European Community's Framework Program FP/2007-2011 under grant agreement no. 212520, as well as the Swiss National Science Foundation.

SIRTA, LHVP are particularly thanked for their strong support in the field.

P. F. D. is grateful for postdoctoral fellowship support from an NSF International Postdoctoral Fellowship (0701013).

Edited by: J.-L. Jimenez

\section{References}

Aiken, A. C., Decarlo, P. F., Kroll, J. H., Worsnop, D. R., Huffman, J. A., Docherty, K. S., Ulbrich, I. M., Mohr, C., Kimmel, J. R., Sueper, D., Sun, Y., Zhang, Q., Trimborn, A., Northway, M., Ziemann, P. J., Canagaratna, M. R., Onasch, T. B., Alfarra, M. R., Prevot, A. S. H., Dommen, J., Duplissy, J., Metzger, A., Baltensperger, U., and Jimenez, J. L.: O/C and OM/OC ratios of primary, secondary, and ambient organic aerosols with high-resolution time-of-flight aerosol mass spectrometry, Environ. Sci. Technol., 42, 4478-4485, 2008.

Aiken, A. C., Salcedo, D., Cubison, M. J., Huffman, J. A., DeCarlo, P. F., Ulbrich, I. M., Docherty, K. S., Sueper, D., Kimmel, J. R., Worsnop, D. R., Trimborn, A., Northway, M., Stone, E. A., Schauer, J. J., Volkamer, R. M., Fortner, E., de Foy, B., Wang, J., Laskin, A., Shutthanandan, V., Zheng, J., Zhang, R., Gaffney, J., Marley, N. A., Paredes-Miranda, G., Arnott, W. P., Molina, L. T., Sosa, G., and Jimenez, J. L.: Mexico City aerosol analysis during MILAGRO using high resolution aerosol mass spectrometry at the urban supersite (T0) - Part 1: Fine particle composition and organic source apportionment, Atmos. Chem. Phys., 9, 6633-6653, doi:10.5194/acp-9-6633-2009, 2009.

Albrecht, B. A.: Aerosols, cloud microphysics, and fractional cloudiness, Science, 245, 1227-1230, 1989.

Alfarra, M. R., Prevot, A. S. H., Szidat, S., Sandradewi, J., Weimer, S., Lanz, V. A., Schreiber, D., Mohr, M., and Baltensperger, U.: Identification of the mass spectral signature of organic aerosols from wood burning emissions, Environ. Sci. Technol., 41, 57705777, 2007.

Allan, J. D., Jimenez, J. L., Williams, P. I., Alfarra, M. R., Bower, K. N., Jayne, J. T., Coe, H., and Worsnop, D. R.: Quantitative sampling using an Aerodyne aerosol mass spectrometer: 1. Techniques of data interpretation and error analysis, J. Geophys. Res.Atmos., 108, 4090, doi:10.1029/2002JD002359, 2003.

Allan, J. D., Delia, A. E., Coe, H., Bower, K. N., Alfarra, M. R., Jimenez, J. L., Middlebrook, A. M., Drewnick, F., Onasch, T. B., Canagaratna, M. R., Jayne, J. T., and Worsnop, D. R.: A generalised method for the extraction of chemically resolved mass spectra from Aerodyne aerosol mass spectrometer data, J. Aerosol Sci., 35, 909-922, 2004.

Allan, J. D., Williams, P. I., Morgan, W. T., Martin, C. L., Flynn, M. J., Lee, J., Nemitz, E., Phillips, G. J., Gallagher, M. W., and Coe, H.: Contributions from transport, solid fuel burning and cooking to primary organic aerosols in two UK cities, Atmos. Chem. Phys., 10, 647-668, doi:10.5194/acp-10-647-2010, 2010.
AMS spectral database: available at: http://cires.colorado.edu/ jimenez-group/AMSsd/\#AmbientDecon, last access: January 2013.

Beekmann, M., Prevot, A. S. H., Drewnick, F., Sciare, J., Pandis, S. N., Denier van der Gon, H. A. C., Crippa, M., Freutel, F., Poulain, L., Ghersi, V., Rodriguez, E., Beirle, S., Zotter, P., von der Weiden-Reinmüller, S.-L., Bressi, M., Fountoukis, C., Petetin, H., Szidat, S., Schneider, J., Rosso, A., El Haddad, I., Megaritis, A., Zhang, Q. J., Slowik, J. G., Moukhtar, S., Kolmonen, P., Stohl, A., Eckhardt, S., Borbon, A., Gros, V., Marchand, N., Jaffrezo, J. L., Schwarzenboeck, A., Colomb, A., Wiedensohler, A., Borrmann, S., Lawrence, M., Baklanov, A., and and Baltensperger, U.: Regional emissions control fine particulate matter levels in the Paris megacity, P. Natl. Acad. Sci., in review, 2013.

Birch, M. E. and Cary, R. A.: Elemental carbon-based method for occupational monitoring of particulate diesel exhaust: Methodology and exposure issues, Analyst, 121, 1183-1190, 1996.

Bond, T. C. and Bergstrom, R. W.: Light absorption by carbonaceous particles: An investigative review, Aerosol Sci. Technol., 40, 27-67, 2006.

Bond, T. C., Streets, D. G., Yarber, K. F., Nelson, S. M., Woo, J. H., and Klimont, Z.: A technology-based global inventory of black and organic carbon emissions from combustion, J. Geophys. Res., 109, D14203, doi:10.1029/2003JD003697, 2004.

Canagaratna, M. R., Jayne, J. T., Ghertner, D. A., Herndon, S., Shi, Q., Jimenez, J. L., Silva, P. J., Williams, P., Lanni, T., Drewnick, F., Demerjian, K. L., Kolb, C. E., and Worsnop, D. R.: Chase studies of particulate emissions from in-use New York City vehicles, Aerosol Sci. Technol., 38, 555-573, 2004.

Canagaratna, M. R., Jayne, J. T., Jimenez, J. L., Allan, J. D., Alfarra, M. R., Zhang, Q., Onasch, T. B., Drewnick, F., Coe, H., Middlebrook, A., Delia, A., Williams, L. R., Trimborn, A. M., Northway, M. J., DeCarlo, P. F., Kolb, C. E., Davidovits, P., and Worsnop, D. R.: Chemical and microphysical characterization of ambient aerosols with the Aerodyne aerosol mass spectrometer, Mass Spectrom. Rev., 26, 185-222, 2007.

Cavalli, F., Viana, M., Yttri, K. E., Genberg, J., and Putaud, J.-P.: Toward a standardised thermal-optical protocol for measuring atmospheric organic and elemental carbon: the EUSAAR protocol, Atmos. Meas. Tech., 3, 79-89, doi:10.5194/amt-3-79-2010, 2010.

Chirico, R., DeCarlo, P. F., Heringa, M. F., Tritscher, T., Richter, R., Prévôt, A. S. H., Dommen, J., Weingartner, E., Wehrle, G., Gysel, M., Laborde, M., and Baltensperger, U.: Impact of aftertreatment devices on primary emissions and secondary organic aerosol formation potential from in-use diesel vehicles: results from smog chamber experiments, Atmos. Chem. Phys., 10, 11545-11563, doi:10.5194/acp-10-11545-2010, 2010.

Chirico, R., Prevot, A. S. H., DeCarlo, P. F., Heringa, M. F., Richter, R., Weingartner, E., and Baltensperger, U.: Aerosol and trace gas vehicle emission factors measured in a tunnel using an aerosol mass spectrometer and other on-line instrumentation, Atmos. Environ., 45, 2182-2192, 2011.

Crippa, M., Canonaco, F., Slowik, J. G., El Haddad, I., DeCarlo, P. F., Mohr, C., Heringa, M., Chirico, R., Marchand, N., Temime, B., Poulain, L., Baltensperger, U., and Prévôt, A. S. H.: Primary and secondary organic aerosols origin from a combined gas-particle phase source apportionment, in preparation, 2013a. 
Crippa, M., El Haddad, I., Slowik, J. G., DeCarlo, P. F., Mohr, C., Heringa, M., Chirico, R., Marchand, N., Sciare, J., Baltensperger, U., and Prévôt, A. S. H.: Identification of marine and continental aerosol sources in Paris using high resolution aerosol mass spectrometry, J. Geophys. Res., 118, 1-19, doi:10.1029/2012JD018694, 2013b.

Cross, E. S., Onasch, T. B., Canagaratna, M., Jayne, J. T., Kimmel, J., Yu, X.-Y., Alexander, M. L., Worsnop, D. R., and Davidovits, P.: Single particle characterization using a light scattering module coupled to a time-of-flight aerosol mass spectrometer, Atmos. Chem. Phys., 9, 7769-7793, doi:10.5194/acp-9-7769-2009, 2009.

Cubison, M. J., Ortega, A. M., Hayes, P. L., Farmer, D. K., Day, D., Lechner, M. J., Brune, W. H., Apel, E., Diskin, G. S., Fisher, J. A., Fuelberg, H. E., Hecobian, A., Knapp, D. J., Mikoviny, T., Riemer, D., Sachse, G. W., Sessions, W., Weber, R. J., Weinheimer, A. J., Wisthaler, A., and Jimenez, J. L.: Effects of aging on organic aerosol from open biomass burning smoke in aircraft and laboratory studies, Atmos. Chem. Phys., 11, 12049-12064, doi:10.5194/acp-11-12049-2011, 2011.

DeCarlo, P. F., Kimmel, J. R., Trimborn, A., Northway, M. J., Jayne, J. T., Aiken, A. C., Gonin, M., Fuhrer, K., Horvath, T., Docherty, K. S., Worsnop, D. R., and Jimenez, J. L.: Field-deployable, high-resolution, time-of-flight aerosol mass spectrometer, Anal. Chem., 78, 8281-8289, 2006.

DeCarlo, P. F., Dunlea, E. J., Kimmel, J. R., Aiken, A. C., Sueper, D., Crounse, J., Wennberg, P. O., Emmons, L., Shinozuka, Y., Clarke, A., Zhou, J., Tomlinson, J., Collins, D. R., Knapp, D., Weinheimer, A. J., Montzka, D. D., Campos, T., and Jimenez, J. L.: Fast airborne aerosol size and chemistry measurements above Mexico City and Central Mexico during the MILAGRO campaign, Atmos. Chem. Phys., 8, 4027-4048, doi:10.5194/acp-84027-2008,

DeCarlo, P. F., Ulbrich, I. M., Crounse, J., de Foy, B., Dunlea, E. J., Aiken, A. C., Knapp, D., Weinheimer, A. J., Campos, T., Wennberg, P. O., and Jimenez, J. L.: Investigation of the sources and processing of organic aerosol over the Central Mexican Plateau from aircraft measurements during MILAGRO, Atmos. Chem. Phys., 10, 5257-5280, doi:10.5194/acp-10-52572010, 2010.

Docherty, K. S., Stone, E. A., Ulbrich, I. M., DeCarlo, P. F., Snyder, D. C., Schauer, J. J., Peltier, R. E., Weber, R. J., Murphy, S. M., Seinfeld, J. H., Grover, B. D., Eatough, D. J., and Jimenez, J. L.: Apportionment of primary and secondary organic aerosols in Southern California during the 2005 study of organic aerosols in Riverside (SOAR-1), Environ. Sci. Technol., 42, 7655-7662, 2008.

Dockery, D. W. and Pope, C. A.: Acute respiratory effects of particulate air-pollution, Annual Review of Public Health, 15, 107132, 1994

Drewnick, F., Hings, S. S., DeCarlo, P., Jayne, J. T., Gonin, M., Fuhrer, K., Weimer, S., Jimenez, J. L., Demerjian, K. L., Borrmann, S., and Worsnop, D. R.: A new time-of-flight aerosol mass spectrometer (TOF-AMS) - Instrument description and first field deployment, Aerosol Sci. Technol., 39, 637-658, 2005.

El Haddad, I., Marchand, N., Temime-Roussel, B., Wortham, H., Piot, C., Besombes, J.-L., Baduel, C., Voisin, D., Armengaud, A., and Jaffrezo, J.-L.: Insights into the secondary fraction of the organic aerosol in a Mediterranean urban area: Marseille,
Atmos. Chem. Phys., 11, 2059-2079, doi:10.5194/acp-11-20592011, 2011.

Elsasser, M., Crippa, M., Orasche, J., DeCarlo, P. F., Oster, M., Pitz, M., Cyrys, J., Gustafson, T. L., Pettersson, J. B. C., SchnelleKreis, J., Prévôt, A. S. H., and Zimmermann, R.: Organic molecular markers and signature from wood combustion particles in winter ambient aerosols: aerosol mass spectrometer (AMS) and high time-resolved GC-MS measurements in Augsburg, Germany, Atmos. Chem. Phys., 12, 6113-6128, doi:10.5194/acp-126113-2012, 2012.

Favez, O., Cachier, H., Sciare, J., and Le Moullec, Y.: Characterization and contribution to PM2.5 of semi-volatile aerosols in Paris (France), Atmos. Environ., 41, 7969-7976, 2007.

Favez, O., Cachier, H., Sciare, J., Sarda-Esteve, R., and Martinon, L.: Evidence for a significant contribution of wood burning aerosols to $\operatorname{PM}(2.5)$ during the winter season in Paris, France, Atmos. Environ., 43, 3640-3644, 2009.

Freutel, F., Schneider, J., Drewnick, F., von der Weiden-Reinmüller, S.-L., Crippa, M., Prévôt, A. S. H., Baltensperger, U., Poulain, L., Wiedensohler, A., Sciare, J., Sarda-Estève, R., Burkhart, J. F., Eckhardt, S., Stohl, A., Gros, V., Colomb, A., Michoud, V., Doussin, J. F., Borbon, A., Haeffelin, M., Morille, Y., Beekmann, M., and Borrmann, S.: Aerosol particle measurements at three stationary sites in the megacity of Paris during summer 2009: meteorology and air mass origin dominate aerosol particle composition and size distribution, Atmos. Chem. Phys., 13, 933-959, doi:10.5194/acp-13-933-2013, 2013.

Gaimoz, C., Sauvage, S., Gros, V., Herrmann, F., Williams, J., Locoge, N., Perrussel, O., Bonsang, B., d'Argouges, O., SardaEsteve, R., and Sciare, J.: Volatile organic compounds sources in Paris in spring 2007. Part II: source apportionment using positive matrix factorisation, Environ. Chem., 8, 91-103, 2011.

Ge, X., Setyan, A., Sun, Y., and Zhang, Q.: Primary and secondary organic aerosols in Fresno, California during wintertime: Results from high resolution aerosol mass spectrometry,, J. Geophys. Res., 117, D19301, doi:10.1029/2012JD018026, 2012.

Gilardoni, S., Liu, S., Takahama, S., Russell, L. M., Allan, J. D., Steinbrecher, R., Jimenez, J. L., De Carlo, P. F., Dunlea, E. J., and Baumgardner, D.: Characterization of organic ambient aerosol during MIRAGE 2006 on three platforms, Atmos. Chem. Phys., 9, 5417-5432, doi:10.5194/acp-9-5417-2009, 2009.

Goldstein, A. H., Worton, D. R., Williams, B. J., Hering, S. V., Kreisberg, N. M., Panic, O., and Gorecki, T.: Thermal desorption comprehensive two-dimensional gas chromatography for in-situ measurements of organic aerosols, Journal of Chromatography A, 1186, 340-347, 2008.

Grieshop, A. P., Donahue, N. M., and Robinson, A. L.: Laboratory investigation of photochemical oxidation of organic aerosol from wood fires 2: analysis of aerosol mass spectrometer data, Atmos. Chem. Phys., 9, 2227-2240, doi:10.5194/acp-9-2227-2009, 2009.

Gros, V., Gaimoz, C., Herrmann, F., Custer, T., Williams, J., Bonsang, B., Sauvage, S., Locoge, N., d'Argouges, O., Sarda-Esteve, R., and Sciare, J.: Volatile organic compounds sources in Paris in spring 2007. Part I: qualitative analysis, Environ. Chem., 8, 74 90, 2011.

Gurjar, B. R., Butler, T. M., Lawrence, M. G., and Lelieveld, J.: Evaluation of emissions and air quality in megacities, Atmos. Environ., 42, 1593-1606, 2008. 
Haeffelin, M., Barthès, L., Bock, O., Boitel, C., Bony, S., Bouniol, D., Chepfer, H., Chiriaco, M., Cuesta, J., Delanoë, J., Drobinski, P., Dufresne, J.-L., Flamant, C., Grall, M., Hodzic, A., Hourdin, F., Lapouge, F., Lemaître, Y., Mathieu, A., Morille, Y., Naud, C., Noël, V., O'Hirok, W., Pelon, J., Pietras, C., Protat, A., Romand, B., Scialom, G., and Vautard, R.: SIRTA, a ground-based atmospheric observatory for cloud and aerosol research, Ann. Geophys., 23, 253-275, doi:10.5194/angeo-23-253-2005, 2005.

Hallquist, M., Wenger, J. C., Baltensperger, U., Rudich, Y., Simpson, D., Claeys, M., Dommen, J., Donahue, N. M., George, C., Goldstein, A. H., Hamilton, J. F., Herrmann, H., Hoffmann, T., Iinuma, Y., Jang, M., Jenkin, M. E., Jimenez, J. L., Kiendler-Scharr, A., Maenhaut, W., McFiggans, G., Mentel, Th. F., Monod, A., Prévôt, A. S. H., Seinfeld, J. H., Surratt, J. D., Szmigielski, R., and Wildt, J.: The formation, properties and impact of secondary organic aerosol: current and emerging issues, Atmos. Chem. Phys., 9, 5155-5236, doi:10.5194/acp-9-51552009, 2009.

He, L.-Y., Lin, Y., Huang, X.-F., Guo, S., Xue, L., Su, Q., Hu, M., Luan, S.-J., and Zhang, Y.-H.: Characterization of highresolution aerosol mass spectra of primary organic aerosol emissions from Chinese cooking and biomass burning, Atmos. Chem. Phys., 10, 11535-11543, doi:10.5194/acp-10-11535-2010, 2010.

Hennigan, C. J., Sullivan, A. P., Collett, J. L., and Robinson, A. L.: Levoglucosan stability in biomass burning particles exposed to hydroxyl radicals, Geophys. Res. Lett., 37, L09806, doi:10.1029/2010GL043088, 2010.

Heringa, M. F., DeCarlo, P. F., Chirico, R., Tritscher, T., Dommen, J., Weingartner, E., Richter, R., Wehrle, G., Prévôt, A. S. H., and Baltensperger, U.: Investigations of primary and secondary particulate matter of different wood combustion appliances with a high-resolution time-of-flight aerosol mass spectrometer, Atmos. Chem. Phys., 11, 5945-5957, doi:10.5194/acp-11-59452011, 2011.

Huang, X.-F., He, L.-Y., Hu, M., Canagaratna, M. R., Sun, Y., Zhang, Q., Zhu, T., Xue, L., Zeng, L.-W., Liu, X.-G., Zhang, Y.-H., Jayne, J. T., Ng, N. L., and Worsnop, D. R.: Highly time-resolved chemical characterization of atmospheric submicron particles during 2008 Beijing Olympic Games using an Aerodyne High-Resolution Aerosol Mass Spectrometer, Atmos. Chem. Phys., 10, 8933-8945, doi:10.5194/acp-10-8933-2010, 2010.

IPCC: Fourth assessment report: The physical science basis, working group I, Final report, Geneva, Switzerland, available at: http: //www.ipcc.ch/ipccreports/ar4-wg1.htm, 2007.

Jimenez, J. L., Canagaratna, M. R., Donahue, N. M., Prevot, A. S. H., Zhang, Q., Kroll, J. H., DeCarlo, P. F., Allan, J. D., Coe, H., Ng, N. L., Aiken, A. C., Docherty, K. S., Ulbrich, I. M., Grieshop, A. P., Robinson, A. L., Duplissy, J., Smith, J. D., Wilson, K. R., Lanz, V. A., Hueglin, C., Sun, Y. L., Tian, J., Laaksonen, A., Raatikainen, T., Rautiainen, J., Vaattovaara, P., Ehn, M., Kulmala, M., Tomlinson, J. M., Collins, D. R., Cubison, M. J., Dunlea, E. J., Huffman, J. A., Onasch, T. B., Alfarra, M. R., Williams, P. I., Bower, K., Kondo, Y., Schneider, J., Drewnick, F., Borrmann, S., Weimer, S., Demerjian, K., Salcedo, D., Cottrell, L., Griffin, R., Takami, A., Miyoshi, T., Hatakeyama, S., Shimono, A., Sun, J. Y., Zhang, Y. M., Dzepina, K., Kimmel, J. R., Sueper, D., Jayne, J. T., Herndon, S. C., Trimborn, A. M., Williams, L. R., Wood, E. C., Middlebrook, A. M., Kolb, C.
E., Baltensperger, U., and Worsnop, D. R.: Evolution of organic aerosols in the atmosphere, Science, 326, 1525-1529, 2009.

Kirchstetter, T. W., Novakov, T., and Hobbs, P. V.: Evidence that the spectral dependence of light absorption by aerosols is affected by organic carbon, J. Geophys. Res.-Atmos., 109, D21208, doi:10.1029/2004JD004999, 2004.

Lanz, V. A., Alfarra, M. R., Baltensperger, U., Buchmann, B., Hueglin, C., and Prévôt, A. S. H.: Source apportionment of submicron organic aerosols at an urban site by factor analytical modelling of aerosol mass spectra, Atmos. Chem. Phys., 7, 15031522, doi:10.5194/acp-7-1503-2007, 2007.

Lanz, V. A., Alfarra, M. R., Baltensperger, U., Buchmann, B., Hueglin, C., Szidat, S., Wehrli, M. N., Wacker, L., Weimer, S., Caseiro, A., Puxbaum, H., and Prevot, A. S. H.: Source attribution of submicron organic aerosols during wintertime inversions by advanced factor analysis of aerosol mass spectra, Environ. Sci. Technol., 42, 214-220, 2008.

Lanz, V. A., Prévôt, A. S. H., Alfarra, M. R., Weimer, S., Mohr, C., DeCarlo, P. F., Gianini, M. F. D., Hueglin, C., Schneider, J., Favez, O., D’Anna, B., George, C., and Baltensperger, U.: Characterization of aerosol chemical composition with aerosol mass spectrometry in Central Europe: an overview, Atmos. Chem. Phys., 10, 10453-10471, doi:10.5194/acp-10-10453-2010, 2010.

Lawrence, M. G., Butler, T. M., Steinkamp, J., Gurjar, B. R., and Lelieveld, J.: Regional pollution potentials of megacities and other major population centers, Atmos. Chem. Phys., 7, 39693987, doi:10.5194/acp-7-3969-2007, 2007.

Lee, B. H., Kostenidou, E., Hildebrandt, L., Riipinen, I., Engelhart, G. J., Mohr, C., DeCarlo, P. F., Mihalopoulos, N., Prevot, A. S. H., Baltensperger, U., and Pandis, S. N.: Measurement of the ambient organic aerosol volatility distribution: application during the Finokalia Aerosol Measurement Experiment (FAME2008), Atmos. Chem. Phys., 10, 12149-12160, doi:10.5194/acp10-12149-2010, 2010.

MEGAPOLI project: available at: http://megapoli.dmi.dk/index. html, last access: January 2013.

McCreanor, J., Cullinan, P., Nieuwenhuijsen, M. J., Stewart-Evans, J., Malliarou, E., Jarup, L., Harrington, R., Svartengren, M., Han, I., Ohman-Strickland, P., Chung, K. F., and Zhang, J. F.: Respiratory effects of exposure to diesel traffic in persons with asthma, New England Journal of Medicine, 357, 2348-2358, 2007.

Mohr, C., DeCarlo, P. F., Heringa, M. F., Chirico, R., Slowik, J. G., Richter, R., Reche, C., Alastuey, A., Querol, X., Seco, R., Peñuelas, J., Jiménez, J. L., Crippa, M., Zimmermann, R., Baltensperger, U., and Prévôt, A. S. H.: Identification and quantification of organic aerosol from cooking and other sources in Barcelona using aerosol mass spectrometer data, Atmos. Chem. Phys., 12, 1649-1665, doi:10.5194/acp-12-1649-2012, 2012.

Molina, M. J. and Molina, L. T.: Megacities and atmospheric pollution, J. Air Waste Manage. Assoc., 54, 644-680, 2004a.

Molina, L. T. and Molina, M. J.: Improving air quality in megacities - Mexico City Case Study, Urban Biosphere and Society: Partnership of Cities, 1023, 142-158, 2004b.

Molina, L. T., Madronich, S., Gaffney, J. S., Apel, E., de Foy, B., Fast, J., Ferrare, R., Herndon, S., Jimenez, J. L., Lamb, B., Osornio-Vargas, A. R., Russell, P., Schauer, J. J., Stevens, P. S., Volkamer, R., and Zavala, M.: An overview of the MILAGRO 2006 Campaign: Mexico City emissions and their transport and transformation, Atmos. Chem. Phys., 10, 8697-8760, 
doi:10.5194/acp-10-8697-2010, 2010.

Ng, N. L., Canagaratna, M. R., Zhang, Q., Jimenez, J. L., Tian, J., Ulbrich, I. M., Kroll, J. H., Docherty, K. S., Chhabra, P. S., Bahreini, R., Murphy, S. M., Seinfeld, J. H., Hildebrandt, L., Donahue, N. M., DeCarlo, P. F., Lanz, V. A., Prévôt, A. S. H., Dinar, E., Rudich, Y., and Worsnop, D. R.: Organic aerosol components observed in Northern Hemispheric datasets from Aerosol Mass Spectrometry, Atmos. Chem. Phys., 10, 46254641, doi:10.5194/acp-10-4625-2010, 2010.

Orsini, D. A., Ma, Y. L., Sullivan, A., Sierau, B., Baumann, K., and Weber, R. J.: Refinements to the particle-into-liquid sampler (PILS) for ground and airborne measurements of water soluble aerosol composition, Atmos. Environ., 37, 1243-1259, 2003.

Paatero, P.: Least squares formulation of robust non-negative factor analysis, Chemom. Intell. Lab. Syst., 37, 23-35, 1997.

Paatero, P.: User's guide for positive matrix factorization programs PMF2.EXE and PMF3.EXE University of Helsinki, Finland, 2007.

Paatero, P. and Hopke, P. K.: Discarding or downweighting highnoise variables in factor analytic models, Anal. Chim. Acta, 490, 277-289, 2003.

Paatero, P. and Hopke, P. K.: Rotational tools for factor analytic models, J. Chemom., 23, 91-100, 2009.

Paatero, P. and Tapper, U.: Positive matrix factorization - a nonnegative factor model with optimal utilization of error-estimates of data values, Environmetrics, 5, 111-126, 1994.

Paatero, P., Hopke, P. K., Song, X. H., and Ramadan, Z.: Understanding and controlling rotations in factor analytic models, Chemom. Intell. Lab. Syst., 60, 253-264, 2002.

Piot, C., Jaffrezo, J.-L., Cozic, J., Pissot, N., El Haddad, I., Marchand, N., and Besombes, J.-L.: Quantification of levoglucosan and its isomers by high performance liquid chromatographyelectrospray ionization tandem mass spectrometry and its applications to atmospheric and soil samples, Atmos. Meas. Tech., 5, 141-148, doi:10.5194/amt-5-141-2012, 2012.

Pope, C. A. and Dockery, D. W.: Health effects of fine particulate air pollution: Lines that connect, J. Air Waste Manage. Assoc., 56, 709-742, 2006.

Puxbaum, H., Caseiro, A., Sanchez-Ochoa, A., Kasper-Giebl, A., Claeys, M., Gelencser, A., Legrand, M., Preunkert, S., and Pio, C.: Levoglucosan levels at background sites in Europe for assessing the impact of biomass combustion on the European aerosol background, J. Geophys. Res.-Atmos., 112, D23S05, doi:10.1029/2006JD008114, 2007.

Robinson, A. L., Subramanian, R., Donahue, N. M., BernardoBricker, A., and Rogge, W. F.: Source apportionment of molecular markers and organic aerosol. 3. Food cooking emissions, Environ. Sci. Technol., 40, 7820-7827, 2006.

Sandradewi, J., Prevot, A. S. H., Szidat, S., Perron, N., Alfarra, M. R., Lanz, V. A., Weingartner, E., and Baltensperger, U.: Using aerosol light absorption measurements for the quantitative determination of wood burning and traffic emission contributions to particulate matter, Environ. Sci. Technol., 42, 3316-3323, 2008.

Sciare, J., d'Argouges, O., Zhang, Q. J., Sarda-Estève, R., Gaimoz, C., Gros, V., Beekmann, M., and Sanchez, O.: Comparison between simulated and observed chemical composition of fine aerosols in Paris (France) during springtime: contribution of regional versus continental emissions, Atmos. Chem. Phys., 10, 11987-12004, doi:10.5194/acp-10-11987-2010, 2010.
Sciare, J., D’Argouges, O., Estève, R. S., Gaimoz, C., Dolgorouky, C., Bonnaire, N., Favez, O., Bonsang, B., and Gros, V.: Large contribution of water insoluble secondary organic aerosols in the region of Paris (France) during wintertime, J. Geophys. Res., 116, D22203, doi:10.1029/2011JD015756, 2011.

Seinfeld, J. H. and Pandis, S. N.: Atmospheric Chemistry and Physics: From Air Pollution to Climate Change, 2nd ed., John Wiley \& Sons, Inc., New York, 2006.

Simoneit, B. R. T., Schauer, J. J., Nolte, C. G., Oros, D. R., Elias, V. O., Fraser, M. P., Rogge, W. F., and Cass, G. R.: Levoglucosan, a tracer for cellulose in biomass burning and atmospheric particles, Atmos. Environ., 33, 173-182, 1999.

Slowik, J. G., Vlasenko, A., McGuire, M., Evans, G. J., and Abbatt, J. P. D.: Simultaneous factor analysis of organic particle and gas mass spectra: AMS and PTR-MS measurements at an urban site, Atmos. Chem. Phys., 10, 1969-1988, doi:10.5194/acp-10-19692010, 2010.

Sun, J., Zhang, Q., Canagaratna, M. R., Zhang, Y., Ng, N. L., Sun, Y., Jayne, J. T., Zhang, X., Zhang, X., and Worsnop, D. R.: Highly time- and size-resolved characterization of submicron aerosol particles in Beijing using an Aerodyne aerosol mass spectrometer, Atmos. Environ., 44, 131-140, 2010.

Sun, Y.-L., Zhang, Q., Schwab, J. J., Demerjian, K. L., Chen, W.N., Bae, M.-S., Hung, H.-M., Hogrefe, O., Frank, B., Rattigan, O. V., and Lin, Y.-C.: Characterization of the sources and processes of organic and inorganic aerosols in New York city with a high-resolution time-of-flight aerosol mass apectrometer, Atmos. Chem. Phys., 11, 1581-1602, doi:10.5194/acp-11-15812011, 2011.

Szidat, S., Jenk, T. M., Synal, H. A., Kalberer, M., Wacker, L., Hajdas, I., Kasper-Giebl, A., and Baltensperger, U.: Contributions of fossil fuel, biomass-burning, and biogenic emissions to carbonaceous aerosols in Zurich as traced by C-14, J. Geophys. Res., 111, D07206, doi:10.1029/2005JD006590, 2006.

Szidat, S., Ruff, M., Perron, N., Wacker, L., Synal, H.-A., Hallquist, M., Shannigrahi, A. S., Yttri, K. E., Dye, C., and Simpson, D.: Fossil and non-fossil sources of organic carbon (OC) and elemental carbon (EC) in Göteborg, Sweden, Atmos. Chem. Phys., 9, 1521-1535, doi:10.5194/acp-9-1521-2009, 2009.

Twomey, S. A., Piepgrass, M., and Wolfe, T. L.: An assessment of the impact of pollution on global cloud albedo, Tellus B, 36, 356366, 1984.

Ulbrich, I. M., Canagaratna, M. R., Zhang, Q., Worsnop, D. R., and Jimenez, J. L.: Interpretation of organic components from Positive Matrix Factorization of aerosol mass spectrometric data, Atmos. Chem. Phys., 9, 2891-2918, doi:10.5194/acp-9-2891-2009, 2009.

Volkamer, R., Jimenez, J. L., San Martini, F., Dzepina, K., Zhang, Q., Salcedo, D., Molina, L. T., Worsnop, D. R., and Molina, M. J.: Secondary organic aerosol formation from anthropogenic air pollution: Rapid and higher than expected, Geophys. Res. Lett., 33, L17811, doi:10.1029/2006GL026899, 2006.

Von der Weiden-Reinmüller, S.-L., Drewnick, F., Crippa, M., Prévôt, A. S. H., Meleux, F., Böttger, T., Klimach, T., Zorn, S. R., Diesch, J.-M., Baltensperger, U., Beekmann, M., and Borrmann, S.: On the applicability of mobile aerosol and trace gas measurements for the investigation of characteristics and transformation of megacity emissions: The Paris metropolitan area, Atmos. Chem. Phys., in preparation, 2013. 
Weingartner, E., Saathoff, H., Schnaiter, M., Streit, N., Bitnar, B., and Baltensperger, U.: Absorption of light by soot particles: determination of the absorption coefficient by means of aethalometers, J. Aerosol Sci., 34, 1445-1463, 2003.

Zhang, Q., Jimenez, J. L., Worsnop, D. R., and Canagaratna, M.: A case study of urban particle acidity and its influence on secondary organic aerosol, Environ. Sci. Technol., 41, 3213-3219, 2007.
Zhang, Q., Jimenez, J., Canagaratna, M., Ulbrich, I., Ng, N., Worsnop, D., and Sun, Y.: Understanding atmospheric organic aerosols via factor analysis of aerosol mass spectrometry: a review, Anal. Bioanal. Chem., 401, 3045-3067, 2011. 